\title{
Functional characterization of the water-soluble organic carbon of size-fractionated aerosol in the southern Mississippi Valley
}

\author{
M.-C. G. Chalbot ${ }^{1}$, J. Brown ${ }^{1}$, P. Chitranshi ${ }^{2}$, G. Gamboa da Costa $^{2}$, E. D. Pollock ${ }^{3}$, and I. G. Kavouras ${ }^{1}$ \\ ${ }^{1}$ University of Arkansas for Medical Sciences, Little Rock, Arkansas, USA \\ ${ }^{2}$ National Center for Toxicological Research, Jefferson, Arkansas, USA \\ ${ }^{3}$ University of Arkansas Stable Isotope Laboratory, Fayetteville, Arkansas, USA
}

Correspondence to: I. G. Kavouras (ikavouras@uams.edu)

Received: 28 January 2014 - Published in Atmos. Chem. Phys. Discuss.: 10 February 2014

Revised: 7 May 2014 - Accepted: 13 May 2014 - Published: 20 June 2014

\begin{abstract}
The chemical content of water-soluble organic carbon (WSOC) as a function of particle size was characterized in Little Rock, Arkansas in winter and spring 2013. The objectives of this study were to (i) compare the functional characteristics of coarse, fine and ultrafine WSOC and (ii) reconcile the sources of WSOC for periods when carbonaceous aerosol was the most abundant particulate component. The WSOC accounted for $5 \%$ of particle mass for particles with $d_{\mathrm{p}}>0.96 \mu \mathrm{m}$ and $10 \%$ of particle mass for particles with $d_{\mathrm{p}}<0.96 \mu \mathrm{m}$. Non-exchangeable aliphatic $(\mathrm{H}-\mathrm{C})$, unsaturated aliphatic $(\mathrm{H}-\mathrm{C}-\mathrm{C}=)$, oxygenated saturated aliphatic $(\mathrm{H}-\mathrm{C}-\mathrm{O})$, acetalic $(\mathrm{O}-\mathrm{CH}-\mathrm{O})$ and aromatic $(\mathrm{Ar}-\mathrm{H})$ protons were determined by proton nuclear magnetic resonance $\left({ }^{1} \mathrm{H}\right.$ NMR). The total non-exchangeable organic hydrogen concentrations varied from $4.1 \pm 0.1 \mathrm{nmol} \mathrm{m}^{-3}$ for particles with $1.5<d_{\mathrm{p}}<3.0 \mu \mathrm{m}$ to $73.9 \pm 12.3 \mathrm{nmol} \mathrm{m}^{-3}$ for particles with $d_{\mathrm{p}}<0.49 \mu \mathrm{m}$. The molar $\mathrm{H} / \mathrm{C}$ ratios varied from $0.48 \pm 0.05$ to $0.92 \pm 0.09$, which were comparable to those observed for combustion-related organic aerosol. The $\mathrm{R}-\mathrm{H}$ was the most abundant group, representing about $45 \%$ of measured total non-exchangeable organic hydrogen concentrations, followed by $\mathrm{H}-\mathrm{C}-\mathrm{O}(27 \%)$ and $\mathrm{H}-\mathrm{C}-\mathrm{C}=(26 \%)$. Levoglucosan, amines, ammonium and methanesulfonate were identified in NMR fingerprints of fine particles. Sucrose, fructose, glucose, formate and acetate were associated with coarse particles. These qualitative differences of ${ }^{1} \mathrm{H}-\mathrm{NMR}$ profiles for different particle sizes indicated the possible contribution of biological aerosols and a mixture of aliphatic and oxygenated compounds from biomass burning and traffic exhausts. The concurrent presence of ammonium and amines also suggested the presence of ammonium/aminium nitrate
\end{abstract}

and sulfate secondary aerosol. The size-dependent origin of WSOC was further corroborated by the increasing $\delta^{13} \mathrm{C}$ abundance from $-26.81 \pm 0.18 \%$ o for the smallest particles to $-25.93 \pm 0.31 \%$ for the largest particles and the relative distribution of the functional groups as compared to those previously observed for marine, biomass burning and secondary organic aerosol. The latter also allowed for the differentiation of urban combustion-related aerosol and biological particles. The five types of organic hydrogen accounted for the majority of WSOC for particles with $d_{\mathrm{p}}>3.0 \mu \mathrm{m}$ and $d_{\mathrm{p}}<0.96 \mu \mathrm{m}$.

\section{Introduction}

Atmospheric aerosols affect climate directly by absorption and scattering of incoming solar radiation and indirectly through their involvement in cloud microphysical processes (Pöschl, 2005; Ghan and Schwartz, 2007). They also influence atmospheric oxidative burden, visibility and human health (Sloane et al., 1991; Cho et al., 2005; Schlesinger et al., 2006). Organic carbon (OC) represents more than $40 \%$ of aerosol mass in urban and continental areas, with the largest fraction of that being soluble in water, yet less than $20 \%$ of that is chemically characterized (Putaud et al., 2004; Goldstein and Galbally, 2007). Moreover, the optical (absorption coefficient $(\sigma(\lambda))$, single scattering albedo $\left.\left(\omega_{o}\right)\right)$ and hydrophilic (vapor pressure $\left(p_{o}^{L}\right)$, evaporation, condensation and repartitioning) properties of organic aerosol cannot be described by any mathematical formulation of the properties of single compounds, since they are related to the number 
and type of chromophore (i.e., functional) groups and supramolecular non-covalent interactions (e.g., hydrogen and van der Walls bonds) (Kavouras and Stephanou, 2002; Cappa et al., 2008; Rincon et al., 2009; Reid et al., 2011). Consequently, the incomplete characterization and the heterogeneity of organic aerosol limit our understanding of their fate and impacts.

OC is composed of primary and secondary compounds originating from anthropogenic and biogenic sources. The water-soluble fraction of organic carbon (WSOC) accounts for 30-90\% of OC, and it is composed of dicarboxylic acids, keto-carboxylic acids, aliphatic aldehydes and alcohols, saccharides, saccharide anhydrides, amines, amino acids, aromatic acids, phenols, organic nitrates and sulfates, and humic and fulvic acids (Timonen et al., 2008; Miyazaki et al., 2009; Pietrogrande et al., 2013; Wozniak et al., 2013). Proton nuclear magnetic resonance $\left({ }^{1} \mathrm{H}-\mathrm{NMR}\right)$ spectroscopy has been applied to characterize the WSOC content of urban, biogenic, marine, continental background and marine aerosol (Suzuki et al., 2001; Graham et al., 2002; Matta et al., 2003; Cavalli et al., 2004; Decesari et al., 2006, 2011; Finessi et al., 2012). Solid-state ${ }^{13} \mathrm{C}$ cross polarized magic angle spinning $\left({ }^{13} \mathrm{C}\right.$ CPMAS) NMR was also used to characterize atmospheric aerosol (Subbalakshmi et al., 2000; Sannigrahi et al., 2006). In addition, the secondary organic aerosol (SOA) composition was studied using two-dimensional (2-D) ${ }^{1} \mathrm{H}-{ }^{1} \mathrm{H}$ correlation spectroscopy (COSY) and ${ }^{1} \mathrm{H}-{ }^{13} \mathrm{C}$ heteronuclear single quantum coherence (HSQC) spectroscopy (Tagliavini et al., 2006; Maksymiuk et al., 2009). The analysis of the WSOC hydrophobic fraction by ${ }^{1} \mathrm{H}$ and $2-\mathrm{D}{ }^{1} \mathrm{H}-{ }^{1} \mathrm{H}$ gradient COSY (gCOSY) NMR allowed for the detection of alkanoic acids based on resonances attributed to terminal methyl $\left(\mathrm{CH}_{3}\right)$ at $\delta 0.8 \mathrm{ppm}, n$-methylenes $\left(n \mathrm{CH}_{2}\right)$ at $\delta 1.3 \mathrm{ppm}$, and $\alpha$ and $\beta$-methylenes $\left(\alpha \mathrm{CH}_{2}, \beta \mathrm{CH}_{2}\right)$ at $\delta 2.2 \mathrm{ppm}$ and $\delta 1.6 \mathrm{ppm}$ (Decesari et al., 2011). Carbohydrates and polyhydroxylated polynuclear aromatic hydrocarbons were identified on urban surface films in Toronto, Canada by ${ }^{1} \mathrm{H}, 2-\mathrm{D}^{1} \mathrm{H}-{ }^{1} \mathrm{H}$ total correlation spectroscopy (TOCSY) and semi-solid-state NMR (Simpson et al., 2006).

Cluster and positive matrix factorization (PMF) were applied to $21{ }^{1} \mathrm{H}$-NMR spectra using 200 (and 400) NMR bands as variables in Mace Head, Ireland (Decesari et al., 2011). Despite the inherent statistical errors associated with the use of a limited number of equations (samples, $n=21$ ) to predict substantially more variables ( $m=200$ or $m=400)$, three to five factors were retained and assigned to methanesulfonate (MSA), amines, clean marine samples, polluted air masses and clean air masses. PMF was also applied to NMR and aerosol mass spectrometer data to apportion the sources of biogenic SOA in the boreal forest (Finessi et al., 2012). The four retained factors were attributed to glycols, humic-like compounds, amines + MSA and biogenic terpene-SOA originating from a polluted environment.

The overall aim of this study was to determine the compositional fingerprints of particulate WSOC for different parti- cle sizes of urban aerosol in Little Rock, Arkansas. The specific objectives were to (i) compare the functional characteristics of coarse, fine and ultrafine WSOC and (ii) to reconcile the sources of WSOC by NMR spectroscopy and ${ }^{13} \mathrm{C}$ isotope ratios. The Little Rock/North Little Rock metropolitan area is a mid-sized Midwestern urban area with $\mathrm{PM}_{2.5}$ (particles with diameter less than $2.5 \mu \mathrm{m}$ ) levels very close to the newly revised annual $\mathrm{PM}_{2.5}$ national ambient air quality standard of $12 \mu \mathrm{g} \mathrm{m}^{-3}$ (Chalbot et al., 2013a). OC was the predominant component, representing approximately $\sim 55 \%$ of $\mathrm{PM}_{2.5}$ mass, with the highest concentrations being measured during winter. The sources of fine atmospheric aerosol in the region included primary traffic particles, secondary nitrate and sulfate, biomass burning, diesel particles, aged/contaminated sea salt and mineral/road dust (Chalbot et al., 2013a). The region also experiences elevated counts of pollen in early spring due to the pollination of oak trees (Dhar et al., 2010). Due to the seasonal variation of weather patterns, the chemical content of aerosol may also be modified by regional transport of cold air masses from the Great Plains and Pacific Northwest in the winter (Chalbot et al., 2013a).

\section{Materials and methods}

\subsection{Sampling}

Seven-day urban size fractionated aerosol samples were collected every second week with a high-volume sampler in Little Rock, Arkansas in the winter and early spring of 2013 (February-March). The sampling duration was selected to reduce the effect of sampling biases (i.e., weekday/weekend or day/night) and obtain sufficient quantities for NMR analysis in each particle size range. The sampling site was located at the north end of the UAMS campus $\left(34^{\circ} 45^{\prime} 3.69^{\prime \prime} \mathrm{N}\right.$ and $\left.92^{\circ} 19^{\prime} 10.28^{\prime \prime} \mathrm{W}\right)$. It was $20 \mathrm{~m}$ above the ground and approximately $100 \mathrm{~m}$ from West Markham Street with annual average daily traffic (AADT) of 13000 vehicles. The I-630 Expressway is located 1 mile to the south of the sampling site (south end of the UAMS campus) with an AADT of 108000 vehicles. The 6-lane ( 3 per direction) highway is an open below surface-level design to reduce air pollution and noise in the adjacent communities.

A five-stage (plus backup filter) Sierra Andersen Model 230 Impactor mounted on a high-volume pump was used (GMWL-2000, Tisch Environmental, Ohio, USA). Particles were separated into six size fractions on quartz fiber filters, according to their aerodynamic cutoff diameters at $50 \%$ efficiency: (i) first stage: > 7.2 $\mu \mathrm{m}$; (ii) second stage: $7.2-3.0 \mu \mathrm{m}$; (iii) third stage: $3.0-1.5 \mu \mathrm{m}$; (iv) fourth stage: $1.5-0.96 \mu \mathrm{m}$; (v) fifth stage: $0.96-0.5 \mu \mathrm{m}$; and (vi) backup filter: $<0.5 \mu \mathrm{m}$, at a nominal flow rate of $1.13 \mathrm{~m}^{3} \mathrm{~min}^{-1}$. We assumed an upper limit of $30 \mu \mathrm{m}$ for the larger particles, in agreement with the specification for the effective cut point for standard highvolume samplers and to facilitate comparison with previous 
studies (Kavouras and Stephanou, 2002). After collection, filters were placed in glass tubes and stored in a freezer at $-30^{\circ} \mathrm{C}$ until extraction and analysis.

\subsection{Materials}

Quartz microfiber filters were purchased from Whatman (QM-A grade, $203 \times 254 \mathrm{~mm}$, Tisch Environmental, USA), were precombusted at $550^{\circ} \mathrm{C}$ for $4 \mathrm{~h}$ and then kept in a dedicated clean glass container, with silica gel, to avoid humidity and contamination. Water (HPLC grade), deuterium oxide (NMR grade, 100 at. \% D), 3-(trimethylsilyl)propionic acidd4 sodium salt ( 98 at. \% D), sodium phosphate buffer (for analysis, 99\%) and sodium azide (extra pure, 99\%) were purchased from Acros Organics (Fisher Scientific Company LLC, USA).

\subsection{Analysis}

A piece of the filters $\left(1 / 10\right.$ of impactor stages $\left(12.5 \mathrm{~cm}^{2}\right)$ and $5.1 \mathrm{~cm}^{2}$ of the backup) was analyzed for $\delta^{13} \mathrm{C}$ by an elemental analyzer (NC2500 Carlo Erba, Milan Italy) interfaced via a Conflo III to a Delta Plus isotope ratio mass spectrometer (Thermo Finnigan, Bremen Germany) at the University of Arkansas Stable Isotope Laboratory. The samples were combusted at $1060^{\circ} \mathrm{C}$ in a stream of helium with an aliquot of oxygen. Nitrogen oxides are reduced in a copper furnace at $600^{\circ} \mathrm{C}$. Resultant gases are separated using a $3 \mathrm{~m}$ chromatography column at $50^{\circ} \mathrm{C}$. Raw data are created using monitor gases, pure nitrogen and carbon dioxide. Raw results are normalized to the Vienna Pee Dee Belemnite (VPDB) using a combination of certified and in-house standards (Nelson, 2000). The relative isotope differences are expressed in permil versus VPDB calculated as follows:

$$
\begin{aligned}
\delta^{13} \mathrm{C}= & {\left[R\left(\left({ }^{13} \mathrm{C} /{ }^{12} \mathrm{C}\right)_{\text {sample }}\right)-R\left(\left({ }^{13} \mathrm{C} /{ }^{12} \mathrm{C}\right)_{\text {standard }}\right) /\right.} \\
& \left.R\left(\left({ }^{13} \mathrm{C} /{ }^{12} \mathrm{C}\right)_{\text {sample }}\right)\right] \times 1000,
\end{aligned}
$$

where $R\left(\left({ }^{13} \mathrm{C} /{ }^{12} \mathrm{C}\right)_{\text {sample }}\right)$ and $R\left(\left({ }^{13} \mathrm{C} /{ }^{12} \mathrm{C}\right)_{\text {standard }}\right)$ (VPDB) are the carbon isotope ratios of the sample and the standard, respectively (Coplen, 2011).

A $1 \mathrm{~cm}^{2}$ piece of each filter was extracted in $1 \mathrm{~mL}$ deionized water and an aliquot $(20 \mu \mathrm{L})$ was analyzed for WSOC using a DRI Model 2001 Thermal/Optical thermal optical reflectance (TOR) carbon analyzer (Atmoslytic Inc., Calabasas, CA) following the Interagency Monitoring of PROtected Visual Environments (IMPROVE) thermal/optical reflectance (TOR) protocol at DRI's Environmental Analysis Facility (Ho et al., 2006).

The remaining portion of each filter was extracted in $50 \mathrm{~mL}$ of ultrapure $\mathrm{H}_{2} \mathrm{O}$ for $1 \mathrm{~h}$ in an ultrasonic bath. The aqueous extract was filtered on a $0.45 \mu \mathrm{m}$ polypropylene filter (Target2, Thermo Scientific), transferred into a pre-weighted vial (for the gravimetric determination of the total watersoluble extract, TWSE), dried using a SpeedVac apparatus and re-dissolved in $500 \mu \mathrm{L}$ of deuterated water $\left(\mathrm{D}_{2} \mathrm{O}\right)$. A microbalance (Mettler-Toledo, model AB265-S) with a precision of $10 \mu \mathrm{g}$ was used in a temperature-controlled environment. To minimize any variation in the $\mathrm{pH}$ of the samples and to block microbial activity, $100 \mu \mathrm{L}$ of a buffer solution of disodium phosphate/monosodium phosphate $(0.2 \mathrm{M}$ $\left.\mathrm{Na}_{2} \mathrm{HPO}_{4} / 0.2 \mathrm{M} \mathrm{NaH}_{2} \mathrm{PO}_{4}, \mathrm{pH} 7.4\right)$ and $100 \mu \mathrm{L}$ of sodium azide $\left(\mathrm{NaN}_{3}\right)(1 \% w / w)$ were added into the sample, respectively. The ${ }^{1} \mathrm{H}$-NMR spectra were obtained on a Bruker Avance $500 \mathrm{MHz}$ instrument equipped with a $5 \mathrm{~mm}$ doubleresonance broad band (BBFO Plus Smart) probe at $298 \mathrm{~K}$ with 3600 scans, using spin lock, an acquisition time of $3.2 \mathrm{~s}$, a relaxation delay of $1 \mathrm{~s}$, and $1 \mathrm{~Hz}$ exponential line broadening and presaturation to the $\mathrm{H}_{2} \mathrm{O}$ resonance (Chalbot et al., 2013b). Spectra were apodized by multiplication, with an exponential decay corresponding to $1 \mathrm{~Hz}$ line broadening in the spectrum and a zero filling factor of 2 . The baseline was manually corrected and integrated using the Advanced Chemistry Development NMR processor (Version 12.01 Academic Edition). The determination of chemical shifts $\left(\delta^{1} \mathrm{H}\right)$ was done relative to that of trimethylsilyl-propionic acid- $\mathrm{d}_{4}$ sodium salt $\left(\mathrm{TSP}-\mathrm{d}_{4}\right)$ (set at $\left.0.0 \mathrm{ppm}\right)$. The segment from $\delta 4.5 \mathrm{ppm}$ to $\delta 5.0 \mathrm{ppm}$, corresponding to the water resonance, was removed from all NMR spectra. We applied the icoshift algorithm to align the NMR spectra (Savorani et al., 2010) and integrated the intensity of signals of individual peaks as well as in five ranges (Decesari et al., 2000, 2001; Suzuki et al., 2001). The saturated aliphatic region $(\mathrm{H}-\mathrm{C}, \delta 0.6-\delta 1.8 \mathrm{ppm})$ was assumed to include protons from methyl, methylene and methine groups $\left(\mathrm{R}-\mathrm{CH}_{3}, \mathrm{R}-\mathrm{CH}_{2}\right.$, and $\mathrm{R}-\mathrm{CH}$, respectively). The unsaturated aliphatic region $(\mathrm{H}-\mathrm{C}-\mathrm{C}=, \delta 1.8$ $\delta 3.2 \mathrm{ppm}$ ) contained signals of protons bound to aliphatic carbon atoms adjacent to a double bond, including allylic $(\mathrm{H}-\mathrm{C}-\mathrm{C}=\mathrm{C})$, carbonyl $(\mathrm{H}-\mathrm{C}-\mathrm{C}=\mathrm{O})$ or imino $(\mathrm{H}-\mathrm{C}-\mathrm{C}=\mathrm{N})$ groups. Secondary or tertiary amines $\left(\mathrm{H}-\mathrm{C}-\mathrm{NR}_{2}\right)$ may also be present in the $\delta 2.2-\delta 2.9 \mathrm{ppm}$ region. The oxygenated saturated aliphatic region $(\mathrm{H}-\mathrm{C}-\mathrm{O}, \delta 3.2-\delta 4.4 \mathrm{ppm})$ contained alcohols, ethers and esters. The fourth region included acetalic protons $(\mathrm{O}-\mathrm{CH}-\mathrm{O})$ with signals of the anomeric proton of carbohydrates and olefins (long-chain $\mathrm{R}-\mathrm{CH}=\mathrm{CH}-$ $\mathrm{R}, \delta 5.0-\delta 6.4 \mathrm{ppm})$. Finally, the fifth region $(\delta 6.5-\delta 8.3 \mathrm{ppm})$ contained aromatic protons $(\mathrm{Ar}-\mathrm{H})$.

\subsection{Calculations}

The Lundgren diagrams and mass median aerodynamic diameter (MMAD) were used to describe the size distribution of particle mass, WSOC and non-exchangeable organic hydrogen concentrations $\left(n_{\text {Conc }}^{\mathrm{o}}\right.$ ) as follows (Van Vaeck and Van Cauwenberghe, 1985; Kavouras and Stephanou, 2002):

$n_{\text {Conc }}^{\mathrm{o}}=\frac{\mathrm{d} C}{C_{\mathrm{t}} \cdot \operatorname{dlog}\left(d_{\mathrm{p}}\right)}$,

where $C$ is the concentration $\left(\mu \mathrm{g} \mathrm{m}^{-3}\right)$ for a given stage, $d_{\mathrm{p}}$ is the aerodynamic diameter $(\mu \mathrm{m})$, and $C_{\mathrm{t}}$ is the total concentration $\left(\mu \mathrm{g} \mathrm{m}^{-3}\right)$. 
MMAD denotes the particle diameter $(\mu \mathrm{m})$ with half of the particle mass, TWSE, WSOC or non-exchangeable organic hydrogen concentration above and the other half below. It was calculated stepwise as follows:

$$
\left(\int_{d_{1}}^{\mathrm{MMAD}} C_{i} d\left(d_{\mathrm{p}}\right)\right)+\sum_{j=1}^{i-1} C_{j}=\frac{1}{2} C_{\mathrm{t}}
$$

where $d_{1}$ is the lower particle size $(\mu \mathrm{m})$ for the $i$-impactor stage; $C_{i}$ and $C_{j}$ are the mass concentrations for the $i$ - and $j$-impactor stages, respectively. If MMAD was higher than the upper particle size collected by the $i$-impactor stage, the calculation was repeated for the next stage. MMAD was calculated for the entire particle range, coarse particles (higher than $3.0 \mu \mathrm{m}$ ) and fine particles (less than $3.0 \mu \mathrm{m}$ ).

Multivariate linear regression analysis was used to attribute WSOC (in $\mathrm{nmol} \mathrm{m}^{-3}$ ) to carbon associated with five types of non-exchangeable organic hydrogen as follows:

$$
\begin{aligned}
\text { WSOC } & =a_{1} \cdot[\mathrm{H}]_{\mathrm{R}-\mathrm{H}}+a_{2} \cdot[\mathrm{H}]_{\mathrm{H}-\mathrm{C}-\mathrm{C}=}+a_{3} \cdot[\mathrm{H}]_{\mathrm{O}-\mathrm{C}-\mathrm{H}} \\
& +a_{4} \cdot[\mathrm{H}]_{\mathrm{O}-\mathrm{CH}-\mathrm{O}}+a_{5} \cdot[\mathrm{H}]_{\mathrm{Ar}-\mathrm{H}}+a_{o},
\end{aligned}
$$

where $\alpha_{1}, \alpha_{2}, \alpha_{3}, \alpha_{4}$ and $\alpha_{5}$ are the regression coefficients of non-exchangeable $\mathrm{R}-\mathrm{H}, \mathrm{H}-\mathrm{C}-\mathrm{C}=, \mathrm{O}-\mathrm{C}-\mathrm{H}, \mathrm{O}-\mathrm{CH}-\mathrm{O}$ and $\mathrm{Ar}-\mathrm{H}$ concentrations (in $\mathrm{nmol} \mathrm{m}{ }^{-3}$ ). The intercept, $\alpha_{0}$, accounted for carbon not associated with the five organic hydrogen types such as carboxylic. The coefficient of variation of the root mean square error, CV(RMSE), was used to evaluate the residuals between measured and predicted WSOC values. It was defined as the RMSE normalized to the mean of the observed values:

$$
\begin{aligned}
& \mathrm{CV}(\mathrm{RMSE})=\frac{\mathrm{RMSE}}{\overline{\mathrm{WSOC}_{\text {measured }}}} \\
& =\frac{\sqrt{\sum_{i=1}^{n}\left(\mathrm{WSOC}_{\text {predicted }, i}-\mathrm{WSOC}_{\text {measured }, i}\right)^{2}}}{n \cdot \overline{\mathrm{WSOC}}_{\text {measured }}},
\end{aligned}
$$

with RMSE being defined as the sample standard deviation of the differences between predicted values and observed values, $\mathrm{n}$ is the number of measurements and $\overline{\mathrm{WSOC}_{\text {measured }}}$ is the average WSOC concentration.

\section{Results and discussion}

Table 1 shows the ambient temperature $\left({ }^{\circ} \mathrm{C}\right)$, barometric pressure (torr), concentrations of major aerosol types and concentration diagnostic ratios of $\mathrm{PM}_{2.5}$ aerosol during the monitoring period at Little Rock at the nearest $\mathrm{PM}_{2.5}$ chemical speciation site (EPA AIRS ID: 051190007; Lat.: $34.756072^{\circ} \mathrm{N}$; Long.: $92.281139^{\circ} \mathrm{W}$ ) (Chalbot et al., 2013a). The site is located $3.6 \mathrm{~km}$ ENE (heading of $77.9^{\circ}$ ) of the UAMS campus. The Interagency Monitoring of PROtected Visibility Environments (IMPROVE) $\mathrm{PM}_{2.5}$ mass reconstruction scheme was used to estimate the mass of the secondary inorganic (sulfate and nitrate) aerosol, organic mass, elemental carbon, soil dust and sea spray (Sisler, 2000).

Organic carbon (OC) was the predominant component of fine aerosol, accounting for $49 \%$ of reconstructed $\mathrm{PM}_{2.5}$ mass, followed by secondary inorganic aerosol $(40 \%)$ and elemental carbon (EC) (7\%), which were comparable to those previously observed for the 2002-2010 period. The OC/EC ratio $(4.58 \pm 1.06)$ was comparable to those observed in the same region for the 2000-2010 period (Chalbot et al., 2013a) that identified biomass burning and traffic as the most important sources of carbonaceous aerosol in the region. This was further corroborated by the prevalence of soluble potassium, a tracer of biomass burning $\left(\mathrm{K}^{+} / \mathrm{K}\right.$ ratio of $\left.1.00 \pm 0.28\right)$ (Zhang et al., 2013). The low $\mathrm{K} / \mathrm{Fe}$ ratio $(0.87 \pm 0.25)$ and the ratios of mineral elements ( $\mathrm{Al}, \mathrm{Si}$ and $\mathrm{Ca}$ ) were comparable to those previously observed in the US demonstrating the presence of soil dust (Kavouras et al., 2009; Chalbot et al., 2013a). The high molar $\mathrm{NH}_{4}^{+} / \mathrm{SO}_{4}^{2-}$ ratio suggested the complete neutralization of sulfate by ammonia, while the $\mathrm{SO}_{4}^{2-} / \mathrm{S}$ suggested the presence of other forms of $\mathrm{S}$ from oil and coal combustion.

\subsection{Size distribution}

The mean ( \pm standard error) of particle mass, total water soluble extract (TWSE), WSOC and non-exchangeable organic hydrogen concentrations for the five regions ( $\mathrm{R}-$ $\mathrm{H}, \mathrm{H}-\mathrm{C}-\mathrm{C}=, \mathrm{H}-\mathrm{C}-\mathrm{O}, \mathrm{O}-\mathrm{CH}-\mathrm{O}$ and $\mathrm{Ar}-\mathrm{H})$ for each particle size range are presented in Table 2 . In Table 2, the mean $\left( \pm\right.$ standard error) molar $\mathrm{H} / \mathrm{C}$ ratio and $\delta^{13} \mathrm{C}$ for each particle size are also reported. The total particle mass concentration ranged from $1.6 \pm 0.1 \mu \mathrm{g} \mathrm{m}^{-3}$ for particles with $0.96<d_{\mathrm{p}}<1.5 \mu \mathrm{m}$ to $11.2 \pm 2.8 \mu \mathrm{g} \mathrm{m}^{-3}$ for particles with $d_{\mathrm{p}}<0.49 \mu \mathrm{m}$. These levels were substantially lower than those measured in other urban areas but comparable to those observed in forests (Kavouras and Stephanou, 2002). The lowest and highest TWSE concentrations were $0.5 \pm 0.1 \mu \mathrm{g} \mathrm{m}^{-3}$ and $5.4 \pm 1.4 \mu \mathrm{g} \mathrm{m}^{-3}$, accounting for about $13 \%$ of the largest $\left(d_{\mathrm{p}}>7.2 \mu \mathrm{m}\right)$ and up to $61 \%$ of the smallest particles $\left(d_{\mathrm{p}}<0.96 \mu \mathrm{m}\right)$, respectively. The WSOC levels were $0.1 \pm 0.1 \mu \mathrm{gC} \mathrm{m}^{-3}$ for particles with $d_{\mathrm{p}}>0.96 \mu \mathrm{m}$ representing $10 \%$ of TWSE and $5 \%$ of particle mass and increased to $1.2 \pm 0.1 \mathrm{\mu g} \mathrm{m}^{-3}$ (22.2\% of TWSE and $10 \%$ of particle mass) for particles with $d_{\mathrm{p}}<0.96 \mu \mathrm{m}$. The contribution of WSOC to particle mass was slightly higher than that computed in Hong Kong for $\mathrm{PM}_{10}$ particles, albeit at substantially lower levels (Ho et al., 2006). For comparison, the WSOC concentrations of size-fractionated aerosol collected during the dry season in the Amazon varied from $0.2(3.5-10 \mu \mathrm{m})$ to $30.4 \mu \mathrm{gC} \mathrm{m}{ }^{-3}(0.42-1.2 \mu \mathrm{m})$ (Tagliavini et al., 2006). The total non-exchangeable organic hydrogen concentrations varied from $4.1 \pm 0.1 \mathrm{nmol} \mathrm{m}^{-3}$ for particles with $0.96<d_{\mathrm{p}}<1.5 \mu \mathrm{m}$ to $73.9 \pm 12.3 \mathrm{nmol} \mathrm{m}^{-3}$ for particles with $d_{\mathrm{p}}<0.49 \mu \mathrm{m}$, with $\mathrm{R}-\mathrm{H}$ being the most abundant group, 
Table 1. Major aerosol types and diagnostic ratios of $\mathrm{PM}_{2.5}$ chemical species in Little Rock, Arkansas during the study period.

\begin{tabular}{lclc}
\hline Variable & $\begin{array}{c}\text { Value } \\
\text { (mean } \pm \text { st. error) }\end{array}$ & Ratio & $\begin{array}{c}\text { Value } \\
\text { (mean } \pm \text { st. error) }\end{array}$ \\
\hline Ambient temperature $\left({ }^{\circ} \mathrm{C}\right)$ & $10.6(6.4-16.6)$ & $\mathrm{OE} / \mathrm{EC}$ & $4.58 \pm 1.06$ \\
Barometric pressure $($ torr $)$ & $758(756-762)$ & $\mathrm{Molar} \mathrm{NH}_{4}^{+} / \mathrm{SO}_{4}^{2-}$ & $3.07 \pm 0.29$ \\
Organic mass $\left(\mu \mathrm{g} \mathrm{m}^{-3}\right)$ & $5.5 \pm 0.9$ & $\mathrm{SO}_{4}^{2-} / \mathrm{S}$ & $2.66 \pm 0.90$ \\
Elemental carbon $\left(\mu \mathrm{g} \mathrm{m}^{-3}\right)$ & $0.7 \pm 0.1$ & $\mathrm{~K}^{+} / \mathrm{K}$ & $1.00 \pm 0.28$ \\
Ammonium sulfate and nitrate $\left(\mu \mathrm{g} \mathrm{m}^{-3}\right)$ & $4.4 \pm 1.6$ & $\mathrm{~K} / \mathrm{Fe}$ & $0.87 \pm 0.25$ \\
Soil dust $\left(\mu \mathrm{g} \mathrm{m}^{-3}\right)$ & $0.5 \pm 0.1$ & $\mathrm{Ni} / \mathrm{V}$ & $0.44 \pm 0.41$ \\
Sea spray $\left(\mu \mathrm{g} \mathrm{m}^{-3}\right)$ & $0.1 \pm 0.1$ & $\mathrm{Al} / \mathrm{Si}$ & $0.40 \pm 0.20$ \\
& & $\mathrm{Al} / \mathrm{Ca}$ & $1.71 \pm 0.82$ \\
\hline
\end{tabular}

representing about $45 \%$ of measured total non-exchangeable organic hydrogen concentrations followed by $\mathrm{H}-\mathrm{C}-\mathrm{O}(27 \%)$ and $\mathrm{H}-\mathrm{C}-\mathrm{C}=(26 \%)$.

The molar $\mathrm{H} / \mathrm{C}$ ratio may provide information on the types of sources; however, it should be cautiously evaluated because of the inherent inability to identify exchangeable protons in hydroxyl, carboxylic and amine functional groups at neutral $\mathrm{pH}$ values by ${ }^{1} \mathrm{H}-\mathrm{NMR}$ (Duarte et al., 2007). H / C values higher than 2 were indicative of compounds with strong aliphatic components, while $\mathrm{H} / \mathrm{C}$ values from 1 to 2 were typically associated with oxygenated or nitro-organic species, and $\mathrm{H} / \mathrm{C}$ values lower than 1 suggested an aromatic signature (Fuzzi et al., 2001). The $\mathrm{H} / \mathrm{C}$ molar ratios were $0.84 \pm 0.02$ and $0.92 \pm 0.09$ for particles with $d_{\mathrm{p}}>3.0 \mu \mathrm{m}$, decreased to $0.48 \pm 0.05$ for particles with $0.96<d_{\mathrm{p}}<3.0 \mu \mathrm{m}$ and increased to $0.54 \pm 0.05$ and $0.73 \pm 0.02$ for smaller particles $\left(d_{\mathrm{p}}<0.96 \mu \mathrm{m}\right)$. In a previous study, the molar $\mathrm{H} / \mathrm{C}$ ratios for vegetation combustion and prescribed fire emissions collected very close to the fire front were 0.39 and 0.64 0.68 , respectively, suggesting a strong polyaromatic content that was typically observed in combustion-related processes (Adler et al., 2011; Chalbot et al., 2013b).

The normalized concentration-based size distributions (i.e., Lundgren diagrams, Van Vaeck and Van Cauwenberghe, 1985) of particle mass, TWSE, WSOC and total nonexchangeable organic hydrogen concentrations are presented in Fig. 1a and b, respectively. Table 3 also shows the mass median aerodynamic diameter for each measured variable. Particle mass and TWSE followed a bimodal distribution with local maxima for particles with $0.49<d_{\mathrm{p}}<1.5 \mu \mathrm{m}$ and $3.0<d_{\mathrm{p}}<7.2 \mu \mathrm{m}$. The first mode (i.e., fine particles) corresponded to MMADs of $0.39 \pm 0.03 \mu \mathrm{m}$ for particle mass and $0.39 \pm 0.02 \mu \mathrm{m}$ for TWSE, which was typical of those observed in other urban areas (Table 3) (Aceves and Grimalt, 1993; Kavouras and Stephanou, 2002). The MMADs of particle mass and TWSE for the second mode (i.e., coarse particles) were $9.15 \pm 2.75 \mu \mathrm{m}$ and $6.35 \pm 0.45 \mu \mathrm{m}$, suggesting the presence of water-insoluble species (e.g., metal oxides) in larger particles $\left(d_{\mathrm{p}}>7.2 \mu \mathrm{m}\right)$. The MMADs calculated for the whole range of particle sizes were $0.68 \pm 0.48 \mu \mathrm{m}$ and
$0.46 \pm 0.02 \mu \mathrm{m}$ for particle mass and TWSE, respectively. This confirmed the accumulation of water-soluble species in the fine range. For WSOC and non-exchangeable organic hydrogen, the size distribution illustrated a one-mode pattern maximizing at particles with $0.49<d_{\mathrm{p}}<1.5 \mu \mathrm{m}$ and corresponding to MMADs for the whole range of particle sizes of $0.43 \pm 0.02 \mu \mathrm{m}$ for WSOC and $0.41 \pm 0.01 \mu \mathrm{m}$ for non-exchangeable organic hydrogen. Coarse particles $(>3.0 \mu \mathrm{m})$ had an MMAD of $11.83 \pm 2.20 \mu \mathrm{m}$ for WSOC and $11.35 \pm 1.45 \mu \mathrm{m}$, which was substantially higher than that computed for particle mass and TWSE, indicating the possible contribution of very large carbonaceous particles. Pollen particles from oak trees (Quercus) have diameters from 6.8 to $37 \mu \mathrm{m}$ and only $10 \%$ of them are present in smaller particles $(0.8-3.1 \mu \mathrm{m})$ (Takahashi et al., 1995). The particle diameter of various types of tree and grass pollen ranged from 22 to $115 \mu \mathrm{m}$ (Diehl et al., 2001). On the other hand, the fine particle MMADs for WSOC and non-exchangeable organic hydrogen of fine particles were $0.37 \pm 0.01 \mu \mathrm{m}$ and $0.34 \pm 0.01 \mu \mathrm{m}$ (comparable to those computed for particle mass and TWSE), indicating the considerable influence of WSOC on TWSE and particle mass in this size range.

\subsection{Functional characterization}

The ${ }^{1} \mathrm{H}-\mathrm{NMR}$ spectra of WSOC for different particle sizes are shown in Fig. 2. The structure of the compounds identified and the hydrogen assignment are shown in Fig. 3. The spectra are characterized by a combination of sharp resonances of the most abundant organic species and convoluted resonances of many organic compounds present at low concentrations. This section describes the variability of ${ }^{1} \mathrm{H}$ NMR spectra for different particles sizes in qualitative terms. A limited number of resonances were assigned to specific organic compounds using reference NMR spectra and in comparison with previous studies (Wishart et al., 2009).

The predominant peaks for particles with $d_{\mathrm{p}}<0.49 \mu \mathrm{m}$ were those in the $\delta 0.8 \mathrm{ppm}$ to $\delta 1.8 \mathrm{ppm}$ range, with a somewhat bimodal distribution maximizing at $\delta \sim 0.9 \mathrm{ppm}$ and $\delta \sim 1.3 \mathrm{ppm}$, respectively. They had previously been 
Table 2. Particle mass, TWSE, WSOC and non-exchangeable organic hydrogen concentrations and $\delta^{13} \mathrm{C}$ at each impactor stage for urban aerosol.

\begin{tabular}{|c|c|c|c|c|c|c|}
\hline & \multicolumn{6}{|c|}{ Diameter $(\mu \mathrm{m})$} \\
\hline Particle mass $\left(\mu \mathrm{g} \mathrm{m}^{-3}\right)$ & $3.6 \pm 0.8$ & $3.5 \pm 0.9$ & $1.7 \pm 0.3$ & $1.6 \pm 0.1$ & $2.6 \pm 0.1$ & $11.2 \pm 2.8$ \\
\hline WSOC $\left(\mu \mathrm{g} \mathrm{m}^{-} 3\right)$ & $0.2 \pm 0.1$ & $0.1 \pm 0.1$ & $0.1 \pm 0.1$ & $0.1 \pm 0.1$ & $0.4 \pm 0.1$ & $1.2 \pm 0.2$ \\
\hline Total organic $\mathrm{H}\left(\mathrm{nmol} \mathrm{m}^{-3}\right)$ & $12.5 \pm 0.9$ & $7.8 \pm 1.0$ & $4.1 \pm 0.1$ & $5.7 \pm 1.3$ & $17.4 \pm 3.5$ & $73.9 \pm 12.3$ \\
\hline $\mathrm{R}-\mathrm{H}\left(\mathrm{nmol} \mathrm{m}^{-3}\right)$ & $1.7 \pm 0.3$ & $1.9 \pm 0.4$ & $1.1 \pm 0$ & $2.6 \pm 1.4$ & $9.1 \pm 2.5$ & $33.8 \pm 11.9$ \\
\hline $\mathrm{O}-\mathrm{CH}-\mathrm{O}\left(\mathrm{nmol} \mathrm{m}^{-3}\right)$ & $0.2 \pm 0.2$ & $0.1 \pm 0.2$ & $0.1 \pm 0.1$ & $0.1 \pm 0.1$ & $0.1 \pm 0.1$ & $0.5 \pm 0.4$ \\
\hline $\mathrm{Ar}-\mathrm{H}\left(\mathrm{nmol} \mathrm{m}^{-3}\right)$ & $0.1 \pm 0.1$ & $0.1 \pm 0.1$ & $0.1 \pm 0.1$ & $0.1 \pm 0.1$ & $0.1 \pm 0.1$ & $0.3 \pm 0.2$ \\
\hline Molar H / C ratio & $0.84 \pm 0.02$ & $0.92 \pm 0.09$ & $0.48 \pm 0.02$ & $0.48 \pm 0.02$ & $0.54 \pm 0.05$ & $0.73 \pm 0.02$ \\
\hline$\delta^{13} \mathrm{C}$ & $-25.93 \pm 0.31$ & $-25.83 \pm 0.19$ & $-25.61 \pm 0.05$ & $-26.13 \pm 0.11$ & $-26.76 \pm 0.22$ & $-26.81 \pm 0.18$ \\
\hline
\end{tabular}
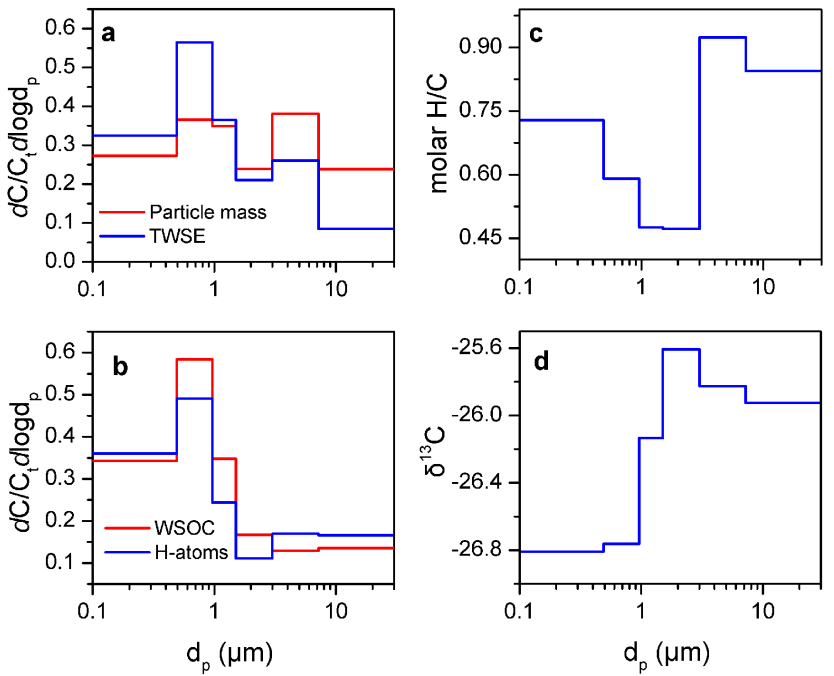

Figure 1. Size distribution for urban particle mass and TWSE (a), WSOC and non-exchangeable organic hydrogen (b), molar $\mathrm{H} / \mathrm{C}$ ratio (c) and $\delta^{13} \mathrm{C}(\mathbf{d})$.

Table 3. Mass median aerodynamic diameter (in $\mu \mathrm{m}$ ) of particle mass, TWSE, WSOC and non-exchangeable organic hydrogen.

\begin{tabular}{lccc}
\hline & Total & Coarse & Fine \\
\hline Particle mass & $0.68 \pm 0.19$ & $9.15 \pm 2.75$ & $0.39 \pm 0.03$ \\
TWSE & $0.46 \pm 0.02$ & $6.35 \pm 0.45$ & $0.39 \pm 0.02$ \\
WSOC & $0.43 \pm 0.02$ & $11.83 \pm 2.20$ & $0.37 \pm 0.01$ \\
Organic hydrogen & $0.41 \pm 0.01$ & $11.35 \pm 1.45$ & $0.34 \pm 0.01$ \\
R-H & $0.37 \pm 0.01$ & $7.00 \pm 0.01$ & $0.34 \pm 0.01$ \\
H-C-C $=$ & $0.41 \pm 0.03$ & $7.13 \pm 0.03$ & $0.37 \pm 0.02$ \\
O-C-H & $0.48 \pm 0.02$ & $13.05 \pm 1.95$ & $0.31 \pm 0.01$ \\
O-CH-O & $0.73 \pm 0.07$ & $10.25 \pm 0.25$ & $0.40 \pm 0.04$ \\
Ar-H & $1.25 \pm 0.65$ & $10.10 \pm 0.90$ & $0.53 \pm 0.12$ \\
\hline
\end{tabular}

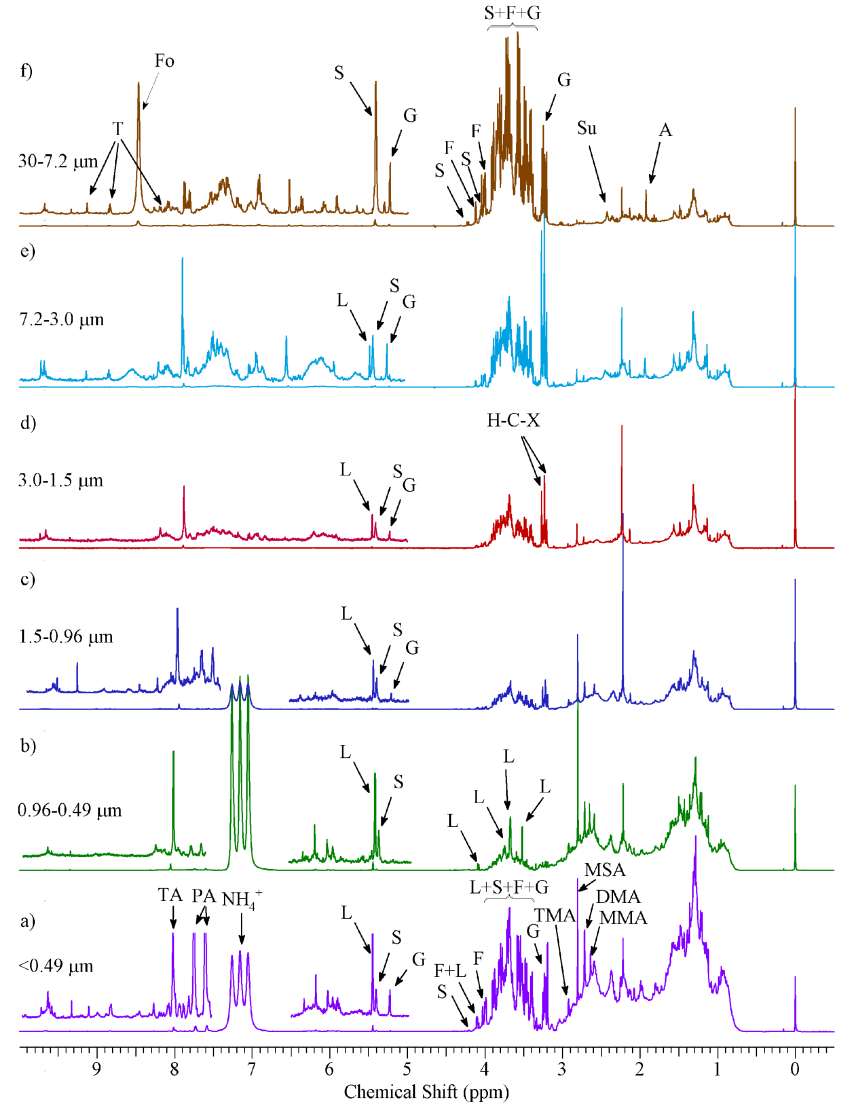

Figure 2. $500 \mathrm{MHz} 1 \mathrm{H}-\mathrm{NMR}$ of size-fractionated WSOC. The segment from $\delta 4.5$ to $\delta 5.0 \mathrm{ppm}$ was removed from all NMR spectra due to $\mathrm{H}_{2} \mathrm{O}$ residues. The peaks were assigned to specific compounds as follows: formate (Fo), levoglucosan (L), glucose $(\mathrm{G})$, sucrose (S), methanesulfonate (MSA), trimethylamine (TMA), succinate $(\mathrm{Su})$, acetate $(\mathrm{A})$, dimethylamine (DMA), monomethylamine (MMA), fructose $(\mathrm{F})$, trigonelline $(\mathrm{T})$, phthalic acid (PA), terephthalic acid (TA), ammonium ions $\left(\mathrm{NH}_{4}^{+}\right)$. 


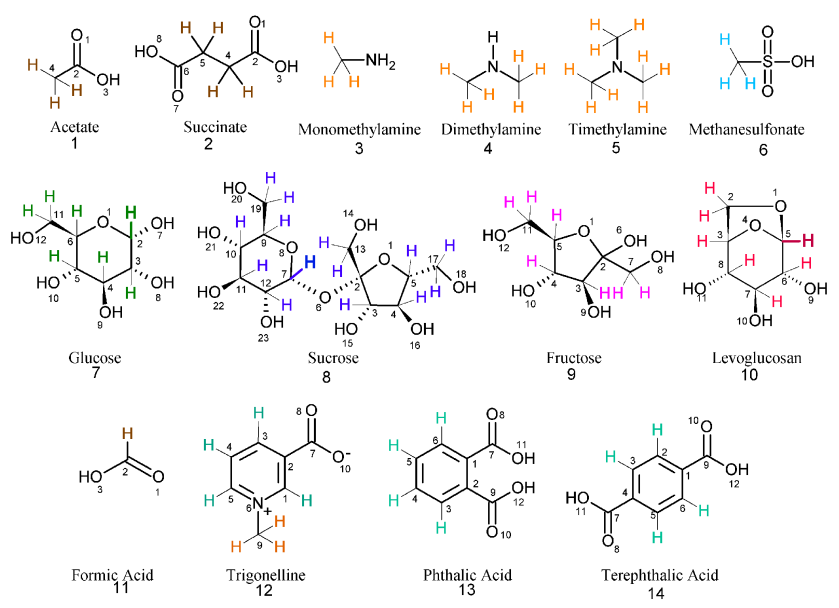

Figure 3. Structures of compounds assigned from the NMR spectra of fractionated aerosols. The protons responsible for the NMR signals are colored as follows: brown (bound to carbon alpha of the carboxylic acid group), orange (methyl groups bound to amines), light blue (bound to carbon alpha of the sulfonic acid group), green (glucose), blue (sucrose), purple (fructose), red (levoglucosan), light green (aromatic hydrogen). The $\mathrm{H}$ in bold indicates the signals in the 5.1-5.7 ppm range (see Fig. 4).

attributed to terminal methyl groups, alkylic protons and protons bound on $\mathrm{C}=\mathrm{O}$ in compounds with a combination of functional groups and long aliphatic chains (Decesari et al., 2001). The ${ }^{1} \mathrm{H}-\mathrm{NMR}$ fingerprint in this region was comparable to that obtained for soil humic compounds, atmospheric humic-like species and urban traffic aerosol (Suzuki et al., 2001; Bartoszeck et al., 2008; Song et al., 2012; Chalbot et al., 2013b). It was previously observed that long chain $\left(C_{6}-C_{30}\right) n$-alkanoic acids, $n$-aldehydes and $n$-alkanes accumulated in particles with $d_{\mathrm{p}}<0.96 \mu \mathrm{m}$ (Kavouras and Stephanou, 2002). The intensity of the convoluted resonances decreased for increasing particle sizes.

In the $\delta 1.8-3.2 \mathrm{ppm}$ range, the sharp resonances at $\delta 1.92 \mathrm{ppm}$ and $\delta 2.41 \mathrm{ppm}$ were previously assigned to aliphatic protons in $\alpha$ position in the $\mathrm{COOH}$ group in acetate (H-4 in Fig. 3) and in succinate (H-4 and H-5 in Fig. 3). These species were observed in the coarse fraction (Fig. 2ef) but not in fine and ultrafine particles (Fig. 2a-c). These two acids (as well as formate) were typically associated with photo-oxidation processes and were present in the accumulation mode; however, Matsumoto et al. (1998) demonstrated that they were also present in sea spray coarse particles. Coarse acetate and formate were also observed in soil dust particles (Chalbot et al., 2013b).

The $\mathrm{CH}_{3}$ in mono-, di- and tri-methylamines (Fig. 3) was allocated to sharp resonances at $\delta 2.59, \delta 2.72$, and $\delta 2.92 \mathrm{ppm}$, respectively. The major source of amines was animal husbandry and they were co-emitted with ammonia (Schade and Crutzen, 1995). They were present as vapors but they partition to aerosol phase by forming non-volatile aminium salts through scavenging by aqueous aerosol and reactions with acids, gas-phase acid-base reactions and displacement of ammonia from pre-existing salts (VandenBoer et al., 2011). The three amines were observed in particles with $d_{\mathrm{p}}<0.96 \mu \mathrm{m}$, which was consistent with previous studies and the suggested gas-to-particle partitioning mechanism (Mueller et al., 2009; Ge et al., 2011). Nitrate and sulfate particles constituted a considerable fraction of fine particles in Little Rock, Arkansas and it was associated with transport of air masses over the Great Plains and Upper Midwest, two regions with many animal husbandry facilities and the highest $\mathrm{NH}_{3}$ emissions in the US (Chalbot et al., 2013a). The presence of aminium/ammonium salts in the water-soluble fraction was also verified by the strong ammonium ${ }^{1} \mathrm{H}-{ }^{14} \mathrm{~N}$ coupling signals at $87.0-7.4 \mathrm{ppm}(1: 1: 1$ triplet, $J_{\mathrm{HN}} \sim 70 \mathrm{~Hz}$ ) (Suzuki et al., 2001). Methanesulfonic acid (MSA) was also present $\left(\mathrm{CH}_{3}\right.$ at $\left.\delta 2.81 \mathrm{ppm}\right)$. MSA is a tracer of marine aerosols, formed from dimethylsulfide oxidation. We previously demonstrated the contribution of marine aerosols originating from the Gulf of Mexico in Little Rock (Chalbot et al., 2013a). MSA was accumulated to fine and ultrafine particles $\left(d_{\mathrm{p}}<1.5 \mu \mathrm{m}\right)$ (Fig. $\left.2 \mathrm{~d}-\mathrm{f}\right)$.

Two segments of the carbohydrate region $(\delta 3.0-4.4 \mathrm{ppm}$ and $\delta 5.1-5.6 \mathrm{ppm})$ of the ${ }^{1} \mathrm{H}-\mathrm{NMR}$ spectra for the largest and smallest particles sizes are presented in Fig. 4a$\mathrm{d}$, respectively. In addition, Fig. $4 \mathrm{e}$ and $\mathrm{f}$ show the combination of individual NMR reference spectra for glucose (HMDB00122), sucrose (HMDB00258), fructose (HMDB00660) and levoglucosan (HMDB00640) retrieved from the Human Metabolome Database (HMDB) NMR databases (Wishart et al., 2009). The ${ }^{1} \mathrm{H}-\mathrm{NMR}$ spectra of size-fractionated WSOC contain both convoluted resonances illustrated by a broad envelope in the spectra, and sharp resonances. For particles with $d_{\mathrm{p}}>7.2 \mu \mathrm{m}$, the spectra were dominated by sharp resonances assigned to glucose $(\mathrm{G}$ in Fig. 2; H-3, multiplet at $\delta 3.24 \mathrm{ppm} ; \mathrm{H}-5$, multiplet at $\delta 3.37-$ 3.43 ppm; H-6, multiplet at $\delta 3.44-3.49$ ppm; H-3, multiplet at $\delta 3.52 \mathrm{ppm} ; \mathrm{H}-4$, multiplet at $\delta 3.68-3.73 \mathrm{ppm} ; \mathrm{H}-$ 11 , multiplet at $83.74-3.77 \mathrm{ppm}$ and $3.88-3.91 \mathrm{ppm}$; H-6 and $\mathrm{H}-11$, multiplet at 3.81-3.85 ppm; and alpha H-2, doublet at $5.23 \mathrm{ppm}$ ), sucrose ( $\mathrm{S}$ in Fig. 2; H-10, multiplet at $3.46 \mathrm{ppm} ; \mathrm{H}-12$, multiplet at $3.55 \mathrm{ppm} ; \mathrm{H}-13$, singlet at $\delta 3.67 \mathrm{ppm} ; \mathrm{H}-11$, multiplet at $3.75 \mathrm{ppm} ; \mathrm{H}-17$ and $\mathrm{H}-19$, multiplet at $\delta 3.82 \mathrm{ppm} ; \mathrm{H}-9$, multiplet at $3.87 \mathrm{ppm} ; \mathrm{H}-5$, multiplet at $3.89 \mathrm{ppm} ; \mathrm{H}-4$, multiplet at $\delta 4.06 \mathrm{ppm} ; \mathrm{H}-3$, doublet at $\delta 4.22 \mathrm{ppm}$ and $\mathrm{H}-7$, doublet at $5.41 \mathrm{ppm})$ and fructose (F in Fig. 2; H-7, multiplet at $\delta 3.55-3.61 \mathrm{ppm}$; $\mathrm{H}-7$ and $\mathrm{H}-11$, multiplet at $\delta 3.66-3.73 \mathrm{ppm} ; \mathrm{H}-3, \mathrm{H}-5$ and $\mathrm{H}-11$, multiplet at $\delta 3.79-3.84 \mathrm{ppm} ; \mathrm{H}-4$, multiplet at $\delta 3.89-3.91 \mathrm{ppm} ; \mathrm{H}-5$ and $\mathrm{H}-11$, multiplet at $\delta 3.99-4.04 \mathrm{ppm} ; \mathrm{H}-3$ and $\mathrm{H}-4$, multiplet at $\delta 4.11-4.12 \mathrm{ppm})$. The overall NMR profile in this range was comparable to that observed for the combination of glucose, sucrose and fructose reference spectra (Fig. 4e and f) and atmospheric pollen (Chalbot et al., 2013c). The intensity of proton resonances in the $\delta 3.30-4.15 \mathrm{ppm}$ range was highest 


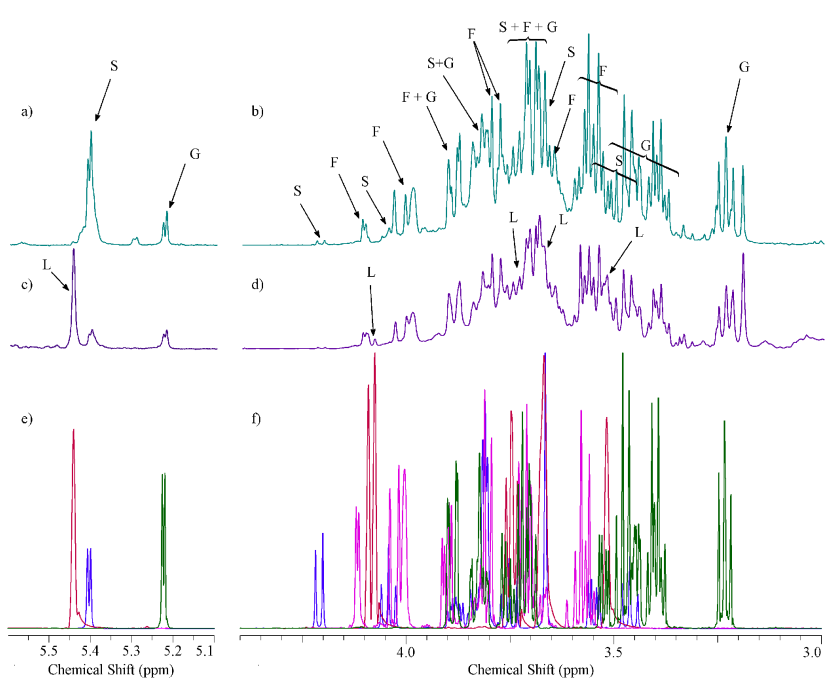

Figure 4. $500 \mathrm{MHz} \delta 3.0-4.4 \mathrm{ppm}$ and $\delta 5.1-5.6 \mathrm{ppm} 1 \mathrm{H}-\mathrm{NMR}$ segments for the largest $(\mathbf{a}, \mathbf{b})$ and smallest particles sizes $(\mathbf{c}, \mathbf{d})$ and reference NMR spectra (e,f) of levoglucosan (red), glucose (green), sucrose (blue) and fructose (purple).

for the largest $\left(d_{\mathrm{p}}>7.2 \mu \mathrm{m}\right)$ and smallest $\left(d_{\mathrm{p}}<0.49 \mu \mathrm{m}\right)$ particles and decreased approximately eight times for particles in the $0.96<d_{\mathrm{p}}<1.5 \mu \mathrm{m}$ size range (Fig. 2a-f). Carbohydrates of biological origin (i.e., pollen) were typically associated with large particles; however, they were also observed in fine biomass burning or biogenic aerosols (Bugni and Ireland, 2004; Medeiros et al., 2006; Agarwal et al., 2010; Fu et al., 2012; Chalbot et al., 2013c). The diameter of airborne fragments of fungal and pathogenic material may be $<1 \mu \mathrm{m}$, with their highest concentrations being measured in fall and spring (Yamamoto et al., 2012). The presence of sugars in particles with $d_{\mathrm{p}}<0.49 \mu \mathrm{m}$ may be due to particle breakup during sampling, an inherent artifact of impaction (Kavouras and Koutrakis, 2001). It has been shown that this error may account for up to $5 \%$ of the particle mass for particles with diameters higher than the cut-off point of the impactor stage. In our study, this would add up to $0.05 \mathrm{nmol} \mathrm{m}^{-3}$ (or $0.2 \%$ ) of the non-exchangeable $\mathrm{H}-\mathrm{C}-\mathrm{O}$ concentration to the concentration of particles with $d_{\mathrm{p}}<0.49 \mu \mathrm{m}$, suggesting the negligible influence of sampling artifacts on the observed size distribution.

Levoglucosan (H-6, multiplet at $\delta 3.52 \mathrm{ppm}$; $\mathrm{H}-7$ and $\mathrm{H}-$ 8 , multiplet at $\delta 3.67 ; \mathrm{H}-2$, multiplet at $\delta 3.73-3.75 \mathrm{ppm}$ and at $4.08 \mathrm{ppm}$; $\mathrm{H}-5$, singlet at $5.45 \mathrm{ppm}(\mathrm{H}-3$ at $4.64 \mathrm{ppm}$; this peak was not visible due to interferences from solvent residues)) was also detected in the carbohydrate region of the ultrafine and fine ${ }^{1} \mathrm{H}$-NMR. Its concentrations, computed using the resonance at $\delta 5.45 \mathrm{ppm}$, ranged from $1.1 \mathrm{ng} \mathrm{m}^{-3}$ for particles with $d_{\mathrm{p}}>7.2 \mu \mathrm{m}$ to $19.1 \mathrm{ng} \mathrm{m}^{-3}$ for particles with $0.49<d_{\mathrm{p}}<0.96 \mu \mathrm{m}$. The mean total concentration was $33.1 \mathrm{ng} \mathrm{m}^{-3}$, which was comparable to those observed in US urban areas (Hasheminassab et al., 2013). Levoglucosan was previously observed in the ${ }^{1} \mathrm{H}-\mathrm{NMR}$ spectra of aerosol samples dominated by biomass burning in the Amazon (Graham et al., 2002).

A group of very sharp resonances between $\delta 3.23$ and $\delta 3.27 \mathrm{ppm}$ was observed with increasing intensity as particle size increased (Fig. 2a-f). These peaks were previously attributed to $\mathrm{H}-\mathrm{C}-\mathrm{X}$ (where $\mathrm{X}=\mathrm{Br}, \mathrm{Cl}$, or I) functional groups (Cavalli et al., 2004).

The intensities of proton resonances in the aromatic region were very low, accounting for 0.3 to $1.2 \%$ of the total non-exchangeable hydrogen concentration, which was consistent with those observed in other studies (Decesari et al., 2007; Cleveland et al., 2012). Resonances were previously attributed to aromatic amino acids and lignin-derived structures, mainly phenyl rings substituted with alcohols $\mathrm{OH}$, methoxy groups $\mathrm{O}-\mathrm{CH}_{3}$ and unsaturated $\mathrm{C}=\mathrm{C}$ bonds, and their combustion products (Duarte et al., 2008). Four organic compounds were identified by means of their NMR reference spectra. These were formate (Fo in Fig. 2; H-2, singlet at $8.47 \mathrm{ppm}$ ), trigonelline ( $\mathrm{T}$ in Fig. 2; $\mathrm{H}-4$, multiplet at $\delta 8.09 \mathrm{ppm} ; \mathrm{H}-5$ and $\mathrm{H}-3$, multiplet at $\delta 8.84 \mathrm{ppm} ; \mathrm{H}-1$, singlet at $\delta 9.13 \mathrm{ppm} ; \mathrm{H}-9$, singlet at $4.42 \mathrm{ppm})$, phthalic acid (P in Fig. 2; H-4 and H-5, multiplet at 87.58 ppm; H-3 and H-6, multiplet at $\delta 7.73 \mathrm{ppm}$ ) and terephthalic acid (TA in Fig. 2; $\mathrm{H}-6, \mathrm{H}-2, \mathrm{H}-5$ and $\mathrm{H}-3$, multiplet at 88.01 ). Formate and trigonelline were only observed in particles with $d_{\mathrm{p}}>7.2 \mu \mathrm{m}$ due to the absorption of formate on pre-existing particles and the biological origin of trigonelline (Chalbot et al., 2013c). The phthalic acid and its isomer, terephthalic acid, were only observed in particles with $d_{\mathrm{p}}<0.49 \mu \mathrm{m}$. These compounds have already been detected in urban areas and vehicular exhausts (Kawamura and Kaplan, 1987; Alier et al., 2013). They may also be formed during the oxidation of aromatic hydrocarbons, but oxidation reactions are not favored by prevailing atmospheric conditions in the winter in the study area (Kawamura and Yasui, 2005).

Overall, the qualitative analysis of 1H-NMR spectra showed the prevalence of sugars in larger particles and a mixture of aliphatic and oxygenated compounds associated with combustion-related sources such as biomass burning and traffic exhausts. The presence of ammonium/aminium salts, probably associated with nitrate and sulfate secondary aerosol, was also identified.

\subsection{Source reconciliation}

The $\delta^{13} \mathrm{C}$ ratios and the relative presence of the different types of protons were further analyzed to identify the sources of WSOC. Stable ${ }^{13} \mathrm{C}$ isotope ratios have been estimated for different types of organic aerosol. The compounds associated with marine aerosols emitted via sea spray have $\delta^{13} \mathrm{C}$ values from -20 to $-22 \%$ (Fontugne and Duplessy, 1981), and a decrease in the $\delta^{13} \mathrm{C}$ to $-26 \pm 2 \%$ of marine tropospheric aerosols has been associated with the presence of continental organic matter (Cachier et al., 1986; Chesselet 


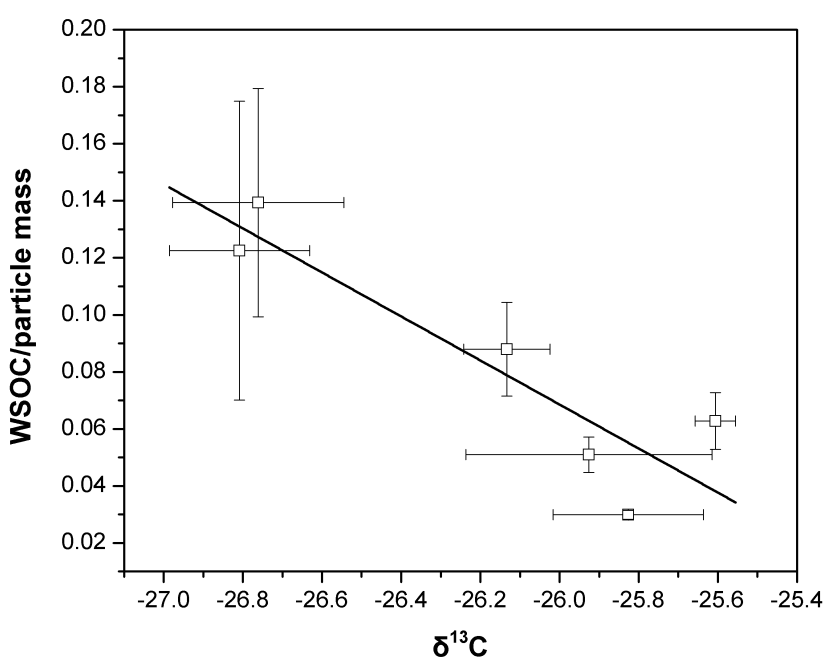

Figure 5. Association of the $13 \mathrm{C}$ isotopic ratio with the $\mathrm{WSOC} /$ particle mass ratio.

et al., 1981). The carbon isotopic ratio of particles from the epicuticular waxes of terrestrial plants is related to the plant physiology and carbon fixation pathways, with $C_{3}$ plants being less enriched in ${ }^{13} \mathrm{C}$ (from $-20 \%$ o to $-32 \%$ ) than the $C_{4}$ plants ( -9 to $-17 \%$ ) (Collister et al., 1994; Ballantine, 1998). The $\delta^{13} \mathrm{C}$ ratios of organic aerosol from combustion of unleaded gasoline and diesel are $-24.2 \pm 0.6 \%$ o and $-26.2 \pm 0.5 \%$, respectively (Widory et al., 2004). Atmospheric aging during transport increases the isotopic ratios (Aggarwal et al., 2013). In our study, the $\delta^{13} \mathrm{C}$ values increased from $-26.81 \pm 0.18 \%$ for the smallest particles $\left(d_{\mathrm{p}}<0.49 \mu \mathrm{m}\right)$ to $-25.93 \pm 0.31 \%$ for the largest particles $\left(d_{\mathrm{p}}>7.2 \mu \mathrm{m}\right)$, indicating a size-dependent mixture of anthropogenic and biogenic sources. Figure 5 shows the association $\left(r^{2}=0.69\right)$ between the WSOC-to-particle mass ratio and $\delta^{13} \mathrm{C}$ for particles with different sizes. The ${ }^{13} \mathrm{C}$ enrichment of WSOC for low WSOC-to-particle mass ratios indicated the negligible effect of atmospheric aging. The predominance of $\mathrm{R}-\mathrm{H}$, moderate $\mathrm{H} / \mathrm{C}$ ratios and low $\delta^{13} \mathrm{C}$ for the smaller particles $\left(d_{\mathrm{p}}<0.96 \mu \mathrm{m}\right)$ were consistent with the contribution of combustion-related sources (Fig. 1c and d). A high $\delta^{13} \mathrm{C}$ ratio, the prevalence of oxygenated groups $(\mathrm{H}-\mathrm{C}-\mathrm{O})$ and a high $\mathrm{H} / \mathrm{C}$ ratio such as those observed for coarse particles $\left(d_{\mathrm{p}}>3.0 \mu \mathrm{m}\right)$ would point towards aged organic aerosol; however, the large size of particles with these characteristics and the low WSOC-to-particle mass ratio suggested the influence of primary biogenic particles (Table 1).

By plotting the ratios of calculated carboxylics and ketones $(\mathrm{H}-\mathrm{C}-\mathrm{C}=\mathrm{O})$ (by subtraction of the $\mathrm{Ar}-\mathrm{H}$ from the $\mathrm{H}-\mathrm{C}-\mathrm{C}=$ region $)$ to the total aliphatics $(\Sigma(\mathrm{H}-\mathrm{C}-))$ and $\mathrm{H}-$ $\mathrm{C}-\mathrm{O} / \Sigma(\mathrm{H}-\mathrm{C}-)$, Decesari et al. (2007) assigned three areas of the plot to OC sources, namely, biomass burning, marine and secondary organic aerosol. The $\Sigma(\mathrm{H}-\mathrm{C}-)$ included the saturated $(\mathrm{H}-\mathrm{C}-\mathrm{O}$, hydroxyls) and the unsaturated oxy-

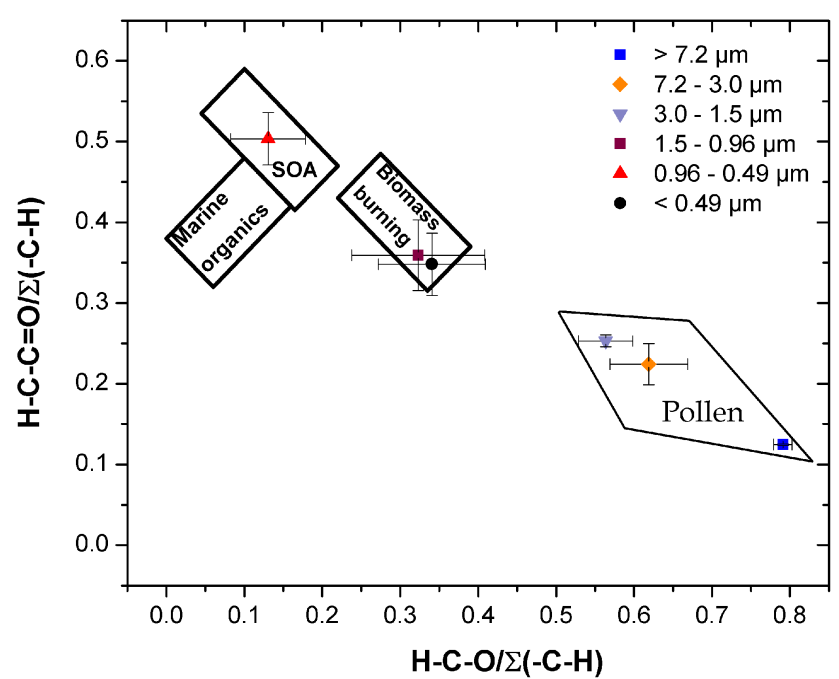

Figure 6. Functional group distributions of WSOC for each impactor stage. The boundaries of biomass burning, marine and secondary organic aerosol were obtained from Decesari et al. (2007).

genated $(\mathrm{HC}-\mathrm{C}=\mathrm{O}$ in acids and ketones) groups, the benzylic $(\mathrm{H}-\mathrm{C}-\mathrm{Ar})$ groups, the unfunctionalized alkyl $(\mathrm{H}-\mathrm{C})$ groups, and minor contributions from other aliphatic groups such as the sulfonic group of MSA. More recently, Cleveland et al. (2012) demonstrated the need to define the boundaries for urban and industrial aerosol that were described by moderate $\mathrm{H}-\mathrm{C}-\mathrm{O} / \Sigma(\mathrm{H}-\mathrm{C}-)$ and $\mathrm{H}-\mathrm{C}-\mathrm{C}=\mathrm{O} / \Sigma(\mathrm{H}-\mathrm{C}-$ ) ratios. Figure 6 depicts the locations of the urban sizefractionated samples collected in this study, in relation to the three aforementioned WSOC sources. Overall, the $\mathrm{H}-$ $\mathrm{C}-\mathrm{C}=\mathrm{O} / \Sigma(\mathrm{H}-\mathrm{C}-)$ ratio increased and the $\mathrm{H}-\mathrm{C}-\mathrm{O} / \Sigma(\mathrm{H}-$ $\mathrm{C}-)$ ratio decreased for decreasing particle sizes. The $\mathrm{H}-$ $\mathrm{C}-\mathrm{C}=\mathrm{O} / \Sigma(\mathrm{H}-\mathrm{C}-)$ varied from 0.12 to 0.50 and the $\mathrm{H}-\mathrm{C}-$ $\mathrm{O} / \Sigma(\mathrm{H}-\mathrm{C}-)$ varied from 0.13 to 0.79 . The data points for the smaller particles $\left(d_{\mathrm{p}}<1.5 \mu \mathrm{m}\right)$ were within the boundaries of biomass burning and SOA, demonstrating the significance of wood burning emissions. The presence of biological aerosol with $d_{\mathrm{p}}>3.0 \mu \mathrm{m}$ yielded low $\mathrm{H}-\mathrm{C}-\mathrm{C}=\mathrm{O} / \Sigma(\mathrm{H}-\mathrm{C}-)$ ratios with a clear separation from combustion-related processes. These findings, in conjunction with those presented by Decesari et al. (2007) and Cleveland et al. (2012), suggest distinct signatures for different sources of organic aerosol that, once defined, may be used to determine the predominant sources of particulate WSOC.

The MMAD for the specific types of organic hydrogen may also provide qualitative information on the origin of organic aerosol. The MMAD of an organic species is found at a significantly smaller particle size than for the total aerosol when condensation (i.e., hot vapors cooling) or a gas-toparticle conversion mechanism prevails. The MMAD for R$\mathrm{H}$ and $\mathrm{H}-\mathrm{C}-\mathrm{C}=$ were comparable, indicating a common origin. Their MMAD values for the total particle size range, coarse particles and fine particles were lower than those 
computed for particle mass and WSOC that can be interpreted by the condensation of hot vapor emissions from fossil fuel combustion and wood burning. This was further corroborated by the similar MMAD values for the total particle size range and fine particles for $\mathrm{R}-\mathrm{H}$ and $\mathrm{H}-\mathrm{C}-\mathrm{C}=$.

However, different trends were observed for $\mathrm{O}-\mathrm{C}-\mathrm{H}, \mathrm{O}-$ $\mathrm{CH}-\mathrm{O}$ and $\mathrm{Ar}-\mathrm{H}$. For $\mathrm{O}-\mathrm{C}-\mathrm{H}$, the MMADs suggested a dual origin: (i) a strong condensation pathway for fine particles with an MMAD value $(0.31 \pm 0.01 \mu \mathrm{m})$ for fine particles that was lower than that for the entire particle size range $(0.48 \pm 0.02 \mu \mathrm{m})$ and fine MMADs for particle mass and WSOC, and (ii) a dominant primary (i.e., direct particle emissions) pathway for coarse particles with the highest MMAD values for all particle metrics in this study $(13.05 \pm 1.95 \mu \mathrm{m})$. Lastly, the high MMAD values for $\mathrm{O}-$ $\mathrm{CH}-\mathrm{O}$ and $\mathrm{Ar}-\mathrm{H}$ for the entire and fine particle size ranges as compared to those computed for the other types of organic hydrogen, particle mass and WSOC pointed towards emissions of primary particles.

\subsection{WSOC reconstruction}

In this section, we estimated the contribution of each type of non-exchangeable organic hydrogen to WSOC levels by regression analysis (Eq. 4) without making any assumptions about the $\mathrm{H} / \mathrm{C}$ ratio. The regression coefficients are estimates of the product of the $\mathrm{H} / \mathrm{C}$ ratio and the relative presence of the functional group in the overall organic composition. Figure 7a presents a comparison between the measured and calculated WSOC levels and Fig. 7b illustrates the attribution of WSOC concentrations to specific types of carbon using the same definitions as for the non-exchangeable protons, i.e., saturated aliphatic $(\mathrm{R}-\mathrm{H})$, unsaturated aliphatic $(\mathrm{H}-\mathrm{C}-\mathrm{C}=)$, oxygenated saturated aliphatic $(\mathrm{H}-\mathrm{C}-\mathrm{O})$, acetalic $(\mathrm{O}-\mathrm{CH}-\mathrm{O})$ and aromatic $(\mathrm{Ar}-\mathrm{H})$, respectively. There was very good agreement $\left(r^{2}=0.99\right.$, slope of 0.9964$)$ between measured WSOC and predicted WSOC concentrations with an CV(RMSE) of 0.02 (or $2 \%$ ). The R-H carbon was the predominant type of WSOC for particles with $d_{\mathrm{p}}<7.2 \mu \mathrm{m}$ (41-60\%) and declined to $28 \%$ for the largest particles. Similarly, the $\mathrm{H}-\mathrm{C}-\mathrm{C}=$ carbon was the second most abundant WSOC type for particles with $d_{\mathrm{p}}<7.2 \mu \mathrm{m}(25-34 \%)$ and declined moderately to $17 \%$ for the largest particles. The $\mathrm{H}-\mathrm{C}-$ O carbon accounted for approximately $49 \%$ of the identified WSOC for particles with $d_{\mathrm{p}}>7.2 \mu \mathrm{m}$ and decreased to $4 \%$ of WSOC for particles with $d_{\mathrm{p}}<1.5 \mu \mathrm{m}$. The contribution of aromatic carbon to WSOC increased from $2 \%$ for the smallest particles to $6 \%$ for the larger particles, while acetalic carbon accounted for $1 \%$ for all particle size ranges. The WSOC not associated with the five carbon types was negligible (less than $1 \%$ ) for particles with $d_{\mathrm{p}}<0.49 \mu \mathrm{m}$ and increased to $47 \%$ of WSOC for particles with $1.5<d_{\mathrm{p}}<3.0 \mu \mathrm{m}$ and $22 \%$ for larger particles. The carbon deficit may be related to carbon associated with carboxylic and/or hydroxyl groups and carbon atoms with no $\mathrm{C}-\mathrm{H}$ bonds (e.g., qua-
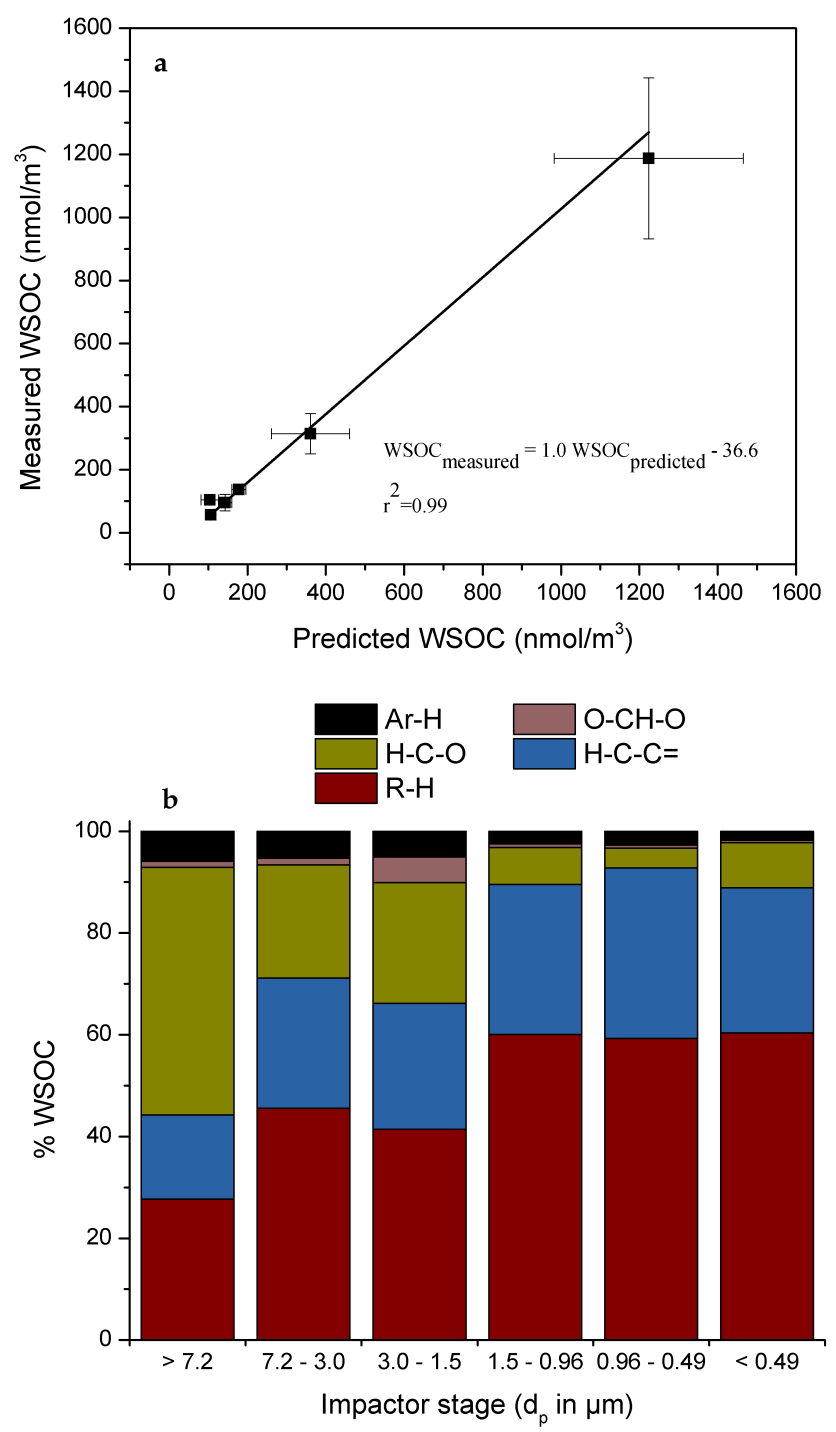

Figure 7. Measured and predicted WSOC concentrations (a) and contributions of $\mathrm{R}-\mathrm{H}, \mathrm{H}-\mathrm{C}-\mathrm{C}=, \mathrm{H}-\mathrm{C}-\mathrm{O}, \mathrm{O}-\mathrm{CH}-\mathrm{O}$ and $\mathrm{Ar}-\mathrm{H}$ on WSOC (b) for each impactor stage of urban aerosol.

ternary C). Alkenoic acids and alcohols in urban environments have been shown to be accumulated in particles with $0.96<d_{\mathrm{p}}<3.0 \mu \mathrm{m}$ (Kavouras and Stephanou, 2002). Overall, this analysis showed that aliphatic carbon originating from anthropogenic sources accounted for the largest fraction of fine and ultrafine WSOC. Sugars and other oxygenated compounds associated with biological particles dominated larger particles. Atmospheric aging appeared to be negligible during the monitoring period.

\section{Conclusions}

The functional characteristic of water soluble organic carbon for different particles sizes in an urban area during winter 
and spring has been studied. Using ${ }^{1} \mathrm{H}-\mathrm{NMR}$ fingerprints, ${ }^{13} \mathrm{C}$ isotopic analysis and molecular tracers, the sources of particulate WSOC were reconciled for specific functional organic groups. A bimodal distribution was drawn for particle mass and water-soluble extract. WSOC and organic hydrogen were distributed between fine particles with MMADs of 0.37 and $0.34 \mu \mathrm{m}$ and coarse particles with MMADs of 11.83 and $11.35 \mu \mathrm{m}$, indicating a mixture of primary large organic aerosol and condensed organic species in the accumulation mode. The NMR spectra for larger particles $\left(d_{\mathrm{p}}>3.0 \mu \mathrm{m}\right)$ demonstrated a strong oxygenated saturated aliphatic content and the presence of fructose, sucrose, glucose, acetate, formate and succinate. These compounds have been previously found in pollen, soil and sea spray particles. For smaller particles $\left(d_{\mathrm{p}}<1.5 \mu \mathrm{m}\right)$, the NMR spectra were dominated by saturated and unsaturated aliphatic protons. Organic species associated with biomass burning (i.e., levoglucosan) and urban traffic emissions (phthalate and terephthalate) were tentatively determined. Furthermore, resonances attributed to ammonium and amines were recognized, suggesting the presence of ammonium/aminium nitrate and sulfate secondary aerosol. The $\delta^{13} \mathrm{C}$ corroborated the local anthropogenic origin of fine and ultrafine organic aerosol. The values of the $\mathrm{H}-$ $\mathrm{C}-\mathrm{C}=\mathrm{O} / \Sigma(\mathrm{H}-\mathrm{C}-)$ and $\mathrm{H}-\mathrm{C}-\mathrm{O} / \Sigma(\mathrm{H}-\mathrm{C}-)$ ratios for the different particle sizes also confirmed the mixed contributions of urban and biomass burning emissions for fine and ultrafine aerosol. The observed distribution of functional groups allowed for the distinct separation of biomass burning and pollen particles, in agreement with previous studies. More than $95 \%$ of WSOC was associated with the five types of non-exchangeable organic hydrogen shown for the largest and smallest particle sizes. Overall, we characterized the WSOC in the southern Mississippi Valley, a region influenced by local anthropogenic sources, intense episodes of pollen, and regional secondary sources of anthropogenic and marine origin. We showed that NMR provides qualitative and, in conjunction with thermal optical reflectance and isotopic analysis, quantitative information on the compositional features of WSOC. Finally, the relative distribution of nonexchangeable organic hydrogen functional groups appeared to be distinctively unique for pollen particles and different than that previously observed for biomass burning and biogenic secondary organic aerosol, indicating that the origin of WSOC may be determined.

Acknowledgements. We would like to thank R. Helm for editing the manuscript. The opinions expressed here do not necessarily represent those of the US Food and Drug Administration.

Edited by: A. Carlton

\section{References}

Aceves, M. and Grimalt, J. O.: Seasonally dependent size distributions of aliphatic and polycyclic aromatic hydrocarbons in urban aerosols from densely populated areas, Environ. Sci. Technol., 27, 2896-2908, 1993.

Adler, G., Flores, J. M., Abo Riziq, A., Borrmann, S., and Rudich, Y.: Chemical, physical, and optical evolution of biomass burning aerosols: a case study, Atmos. Chem. Phys., 11, 1491-1503, doi:10.5194/acp-11-1491-2011, 2011.

Agarwal, S., Aggarwal, S. G., Okuzawa, K., and Kawamura, K.: Size distributions of dicarboxylic acids, ketoacids, $\alpha$ dicarbonyls, sugars, WSOC, OC, EC and inorganic ions in atmospheric particles over Northern Japan: implication for long-range transport of Siberian biomass burning and East Asian polluted aerosols, Atmos. Chem. Phys., 10, 5839-5858, doi:10.5194/acp10-5839-2010, 2010.

Aggarwal, S. G., Kawamura, K., Umarji, G. S., Tachibana, E., Patil, R. S., and Gupta, P. K.: Organic and inorganic markers and stable $\mathrm{C}$-, $\mathrm{N}$-isotopic compositions of tropical coastal aerosols from megacity Mumbai: sources of organic aerosols and atmospheric processing, Atmos. Chem. Phys., 13, 4667-4680, doi:10.5194/acp-13-4667-2013, 2013.

Alier, M., van Drooge, B. L., Dall'Osto, M., Querol, X., Grimalt, J. O., and Tauler, R.: Source apportionment of submicron organic aerosol at an urban background and a road site in Barcelona (Spain) during SAPUSS, Atmos. Chem. Phys., 13, 10353-10371, doi:10.5194/acp-13-10353-2013, 2013.

Ballantine, D. C., Macko, S. A., and Turekian, V. C.: Variability of stable carbon isotopic composition in individual fatty acids from combustion of $\mathrm{C} 4$ and $\mathrm{C} 3$ plants: implications for biomass burning, Chem. Geol., 152, 151-156, 1998.

Bartoszeck, M., Polak, J., and Sulkowski, W. W.: NMR study of the humification process during sewage sludge treatment, Chemosphere, 73, 1465-1470, 2008.

Bugni, T. S. and Ireland, C. M.: Marine-derived fungi: a chemically and biologically diverse group of microorganisms, Nat. Prod. Rep., 21, 143-163, 2004.

Cachier, H., Buat-Menard, P., Fontugne, M., and Chesselet, R.: Long-range transport of continentally-derived particulate carbon in the marine atmosphere: evidence from stable carbon isotopic studies, Tellus B, 38, 161-177, 1986.

Cappa, C. D., Lovejoy, E. R., and Ravishankara, A. R.: Evidence for Liquid-Like and Nonideal Behavior of a Mixture of Organic Aerosol Components, P. Natl. Acad. Sci. USA, 105, 1868718691, 2008.

Cavalli, F., Facchini, M., Decesari, S., Mircea, M., Emblico, L., Fuzzi, S., Ceburnis, D., Yoon, Y., O’Dowd, C., Putaud, J., and Dell'Acqua, A.: Advances in characterization of size-resolved organic matter in marine aerosol over the North Atlantic, J. Geophys. Res.-Atmos., 109, D24215, doi:10.1029/2004JD0051377, 2004.

Chalbot, M.-C., McElroy, B., and Kavouras, I. G.: Sources, trends and regional impacts of fine particulate matter in southern Mississippi valley: significance of emissions from sources in the Gulf of Mexico coast, Atmos. Chem. Phys., 13, 3721-3732, doi:10.5194/acp-13-3721-2013, 2013a.

Chalbot, M. C., Nikolich, G., Etyemezian, V., Dubois, D. W., King., J., Shafer, D., Gamboa Da Costa, G., Hinton., J. F., and Kavouras, I. G.: Soil humic-like organic compounds in prescribed fire 
emissions using nuclear magnetic resonance spectroscopy, Environ. Pollut., 181, 167-171, 2013b.

Chalbot, M. C., Gamboa da Costa, G., and Kavouras I. G.: NMR analysis of the water soluble fraction of airborne pollen particles, Appl. Magn. Reson., 44, 1347-1358, 2013c.

Chesselet, R., Fontugne, M., Buat-Menard, P., Ezat, U., and Lambert, C. E.: The origin of particulate organic carbon in the marine atmosphere as indicated by its stable carbon isotopic composition, Geophys. Res. Lett., 8, 345-348, 1981.

Cho, A. K., Sioutas, C., Miguel, A. H., Kumagai, Y., Schmitz, D. A., Singh, M., Eiguren-Fernandez, A., and Froines, J. R.: Redox activity of airborne particulate matter at different sites in the Los Angeles Basin, Environ. Res., 99, 40-47, 2005.

Cleveland, M. J., Ziemba, L. D., Griffin, R. J., Dibb, J. E., Anderson, C. H., Lefer, B., and Rappenglueck, B.: Characterization of urban aerosol using aerosol mass spectrometry and proton nuclear magnetic resonances, Atmos. Environ., 54, 511-518, 2012.

Collister, J. W., Rieley, G., Stern, B., Eglinton, G., and Fry, B.: Compound-specific delta-C-13 analyses of leaf lipids from plants with differing carbon-dioxide metabolisms, Org. Geochem., 21, 619-627, 1994.

Coplen, T. B.: Guidelines and recommended terms for expression of stable-isotope-ratio and gas-ratio measurement results, Rapid Commun. Mass Sp., 25, 2538-2560, 2011.

Decesari, S., Facchini, M., Fuzzi, S., and Tagliavini, E.: Characterization of water-soluble organic compounds in atmospheric aerosol: A new approach, J. Geophys. Res.-Atmos., 105, 14811489, 2000.

Decesari, S., Facchini, M., Matta, E., Lettini, F., Mircea, M., Fuzzi, S., Tagliavini, E., and Putaud, J.: Chemical features and seasonal variation of fine aerosol water-soluble organic compounds in the Po valley, Italy, Atmos. Environ., 35, 3691-3699, 2001.

Decesari, S., Fuzzi, S., Facchini, M. C., Mircea, M., Emblico, L., Cavalli, F., Maenhaut, W., Chi, X., Schkolnik, G., Falkovich, A., Rudich, Y., Claeys, M., Pashynska, V., Vas, G., Kourtchev, I., Vermeylen, R., Hoffer, A., Andreae, M. O., Tagliavini, E., Moretti, F., and Artaxo, P.: Characterization of the organic composition of aerosols from Rondônia, Brazil, during the LBASMOCC 2002 experiment and its representation through model compounds, Atmos. Chem. Phys., 6, 375-402, doi:10.5194/acp6-375-2006, 2006.

Decesari, S., Mircea, M., Cavalli, F., Fuzzi, S., Moretti, F., Tagliavini, E., and Facchini, M. C.: Source attribution of water-soluble organic aerosol by nuclear magnetic resonance spectroscopy. Environ. Sci. Technol., 41, 2479-2484, 2007.

Decesari, S., Finessi, E., Rinaldi, M., Paglione, M., Fuzzi, S., Stephanou, E. G., Tziaras, T., Spyros, A., Ceburnis, D., O'Dowd, C., Dall'Ostro, M., Harrison, R. M., Allan, J., Coe, H., and Facchini, M. C.: Primary and secondary marine organic aerosols over the North Atlantic Ocean during the MAP experiment. J. Geophys. Res.-Atmos., 116, D22210, doi:10.1029/2011JD016204, 2011.

Dhar, M., Portnoy, J., and Barnes, C.: Oak pollen season in the Midwestern US, J. Allergy Clin. Immun., 125, AB15, doi:10.1016/S0091-6749(10)00024-2, 2010.

Diehl, K., Quick, C., Matthis-Maser, S., Mitra, S. K., and Jaenicke, R.: The ice nucleating ability of pollen Part I: Laboratory studies in deposition and condensation freezing modes, Atmos. Res., 58, 75-87, 2001.
Duarte, R. M. B. O., Santos, E. B. H., Pio, C. A., and Duarte, A. C.: Comparison of structural features of water-soluble organic matter from atmospheric aerosols with those of aquatic humic substances, Atmos. Environ., 41, 8100-8113, 2007.

Duarte, R. M. B. O., Silva, A. M. S., and Duarte, A. C.: Twodimensional NMR studies of water-soluble organic matter in atmospheric aerosols, Environ. Sci. Technol., 42, 8224-8230, 2008.

Finessi, E., Decesari, S., Paglione, M., Giulianelli, L., Carbone, C., Gilardoni, S., Fuzzi, S., Saarikoski, S., Raatikainen, T., Hillamo, R., Allan, J., Mentel, Th. F., Tiitta, P., Laaksonen, A., Petäjä, T., Kulmala, M., Worsnop, D. R., and Facchini, M. C.: Determination of the biogenic secondary organic aerosol fraction in the boreal forest by NMR spectroscopy, Atmos. Chem. Phys., 12, 941-959, doi:10.5194/acp-12-941-2012, 2012.

Fontugne, M. R. and Duplessy, J. C.: Organic-Carbon isotopic fractionation by marine plankton in the temperature-range -1 to 31 degres C, Oceanol. Acta, 4, 85-90, 1981.

Fu, P., Kawamura, K., Kobayashi, M., and Simoneit, B. R. T.: Seasonal variations of sugars in atmospheric particulate matter from gosan, jeju island: Significant contributions of airborne pollen and asian dust in spring, Atmos. Environ., 55, 234-239, 2012.

Fuzzi, S., Decesari, S., Facchini, M. C., Matta, E., Mircea, M., and Tagliavini, E.: A simplified model of the water soluble organic component of atmospheric aerosols, Geophys. Res. Lett. 28, 4079-4082, 2001.

Ge, X., Wexler, A. S., and Clegg, S. L.: Atmospheric Amines - Part 1. A review, Atmos. Environ., 45, 524-546, 2011.

Ghan, S. J. and Schwartz, S. E.: Aerosol properties and processes A path from field and laboratory measurements to global climate models, B. Am. Meteorol. Soc., 88, 1059-1083, 2007.

Goldstein, A. H. and Galbally, I. E.: Known and unexplored organic constituents in the earth's atmosphere, Environ. Sci. Technol., 41, 1514-1521, 2007.

Graham, B., Mayol-Bracero, O., Guyon, P., Roberts, G. C., Decesari, S., Facchini, M. C., Artaxo, P., Maenhaut, W., Köll, P., and Andreae, M. O.: Water-soluble organic compounds in biomass burning aerosols over Amazonia 1. Characterization by NMR and GC-MS, J. Geophys. Res., 107, 8047 , doi:10.1029/2001JD000336, 2002.

Hasheminassab, S., Daher, N., Schauer, J. J., and Sioutas, C.: Source apportionment and organic compound characterization of ambient ultrafine particulate matter (PM) in the Los Angeles Basin, Atmos. Environ., 79, 529-539, 2013.

Ho, K. F., Lee, S. C., Cao, J. J., Li, Y. S., Chow, J. C., Watson, J. G., and Fung, K.: Variability of organic and elemental carbon, water soluble organic carbon, and isotopes in Hong Kong, Atmos. Chem. Phys., 6, 4569-4576, doi:10.5194/acp-6-4569-2006, 2006.

Kavouras, I. G. and Koutrakis, P.: Use of polyurethane foam as the impaction substrate/collection medium in conventional inertial impactors, Aerosol Sci. Tech., 34, 46-56, 2001.

Kavouras, I. G. and Stephanou, E. G.: Particle size distribution of organic primary and secondary aerosol constituents in urban, background marine, and forest atmosphere. J. Geophys. Res., 107, 4069, doi:10.1029/2000JD000278, 2002.

Kavouras, I. G., Etyemezian, V., DuBois, D. W., Xu, J., and Pitchford, M.: Source reconciliation of atmospheric dust causing visibility impairment in Class I areas of the 
western United States, J. Geophys. Res.-Atmos., 114, D02308, doi:10.1029/2008JD009923, 2009.

Kawamura, K. and Kaplan, I. R.: Motor exhaust emissions as a primary source for dicarboxylic acids in Los Angeles ambient air, Environ. Sci. Technol., 21, 105-110, 1987.

Kawamura, K. and Yasui, O.: Diurnal changes in the distribution of dicarboxylic acids, ketocarboxylic acids and dicarbonyls in the urban Tokyo atmosphere, Atmos. Environ., 39, 1945-1960, 2005.

Maksymiuk, C. S., Gayahtri, C., Gil, R. R., and Donahue, N. M.: Secondary organic aerosol formation from multiphase oxidation of limonene by ozone: Mechanistic constraints via twodimensional heteronuclear NMR spectroscopy, Phys. Chem. Chem. Phys., 11, 7810-7818, 2009.

Matsumoto, K., Nagao, I., Tanaka, H., Miyaji, H., Iida, T., and Ikebe, Y.: Seasonal characteristics of organic and inorganic species and their size distributions in atmospheric aerosols over the Northwest Pacific Ocean, Atmos. Environ., 32, 1931-1946, 1998.

Matta, E., Facchini, M. C., Decesari, S., Mircea, M., Cavalli, F., Fuzzi, S., Putaud, J.-P., and Dell'Acqua, A.: Mass closure on the chemical species in size-segregated atmospheric aerosol collected in an urban area of the Po Valley, Italy, Atmos. Chem. Phys., 3, 623-637, doi:10.5194/acp-3-623-2003, 2003.

Medeiros, P. M., Conte, M. H., Weber, J. C., and Simoneit, B. R. T.: Sugars as source indicators of biogenic organic carbon in aerosols collected above the Howland Experimental Forest, Maine, Atmos. Environ., 40, 1694-1705, 2006.

Miyazaki, Y., Kondo, Y., Shiraiwa, M., Takegawa, N., Miyakawa, T., Han, S., Kita, K., Hu, M., Denq, Z. Q., Zhao, Y., Sugimoto, N., Blake, D. R., and Weber, R. J.: Chemical characterization of water-soluble organic carbon aerosols at a rural site in the Pearl River Delta, China, in the summer of 2006, J. Geophys. Res.Atmos., 114, D14208, doi:10.1029/2009JD011736, 2009.

Müller, C., Iinuma, Y., Karstensen, J., van Pinxteren, D., Lehmann, S., Gnauk, T., and Herrmann, H.: Seasonal variation of aliphatic amines in marine sub-micrometer particles at the Cape Verde islands, Atmos. Chem. Phys., 9, 9587-9597, doi:10.5194/acp-99587-2009, 2009.

Nelson, S. T.: A simple, practical methodology for routine VSMOW/SLAP normalization of water samples analyzed by continuous flow methods, Rapid Commun. Mass Sp., 14, 10441046, 2000.

Pietrogrande, M. C., Bacco, D., and Chiereghin, S.: GC/MS analysis of water-soluble organics in atmospheric aerosol: optimization of a solvent extraction procedure for simultaneous analysis of carboxylic acids and sugars, Anal. Bioanal. Chem., 405, 10951104, 2013.

Pöschl, U.: Atmospheric aerosols: Composition, transformation, climate and health effects, Angew. Chem. Int. Edit., 44, 75207540, 2005.

Putaud, J. P., Raes, F., Van Dingenen, R., Bruggermann, E., Facchini, M. C., Decesari, S., Fuzzi, S., Gehrig, R., Huglin, C., Laj, P., Lorbeer, G., Maenhaut, W., Mihalopoulos, N., Muller, K., Querol, X., Rodriguez, S., Schneider, J., Spindler, G., ten Brink, H., Torseth, K., and Wiedensohler, A.: A European aerosol phenomenology-2: Chemical characteristics of particulate matter at kerbside, urban, rural and background sites in Europe, Atmos. Environ., 38, 2579-2595, 2004.
Reid, J. P., Dennis-Smither, B. J., Kwamena, N. O. A., Miles, R. E. H., Hanford, K. L., and Homer, C. J.: The morphology of aerosol particles consisting of hydrophobic and hydrophilic phases: hydrocarbons, alcohols and fatty acids as the hydrophobic component, Phys. Chem. Chem. Phys., 13, 15559-15572, 2011.

Rincon, A. G., Guzman, M. I., Hoffmann, M. R., and Colussi, A. J.: Optical absorptivity versus molecular composition of model organic aerosol matter, J. Phys. Chem., 113, 10512-10520, 2009.

Sannigrahi, P., Sullivan, A., Weber, R., and Ingall, E.: Characterization of water-soluble organic carbon in urban atmospheric aerosols using solid-state C-13 NMR spectroscopy, Environ. Sci. Technol., 40, 666-672, 2006.

Savorani, F., Tomasi, G., and Engelsen, S. B.: icoshift: A versatile tool for the rapid alignment of 1D NMR spectra, J. Magn. Res., 202, 109-202, 2010.

Schade, G. W. and Crutzen, P. J.: Emission of aliphatic amines from animal husbandry and their reactions: potential source of $\mathrm{N}_{2} \mathrm{O}$ and HCN, J. Atmos. Chem., 22, 319-346, 1995.

Schlesinger, R. B., Kunzli, N., Hidy, G. M., Gotschi, T., and Jerrett, M.: The health relevance of ambient particulate matter characteristics: Coherence of toxicological and epidemiological inferences, Inhal. Toxicol., 18, 95-125, 2006.

Simpson, A., Lam, B., Diamond, M. L., Donaldson, D. J., Lefebvre, B. A., Moser, A. Q., Williams, A. J., Larin, N. I., and Kvasha, M. P.: Assessing the organic composition of urban surface films using nuclear magnetic resonance spectroscopy, Chemosphere, 63, 142-152, 2006.

Sisler J. F.: Aerosol mass budget and spatial distribution, in Spatial and Seasonal Pattern and Temporal Variability of Haze and its Constitutents in the United States, Report III, edited by: Malm, W., Colorado State University, Fort Collins, Co, 2000.

Sloane, C. S., Watson, J., Chow, J., Pritchett, L., and Richards, L. W.: Size-segregated fine particle measurements by chemicalspecies and their impact on visibility impairment in Denver, Atmos. Environ. A-Gen., 25, 1013-1024, 1991.

Song, J., He, L., Peng, P., Zhao, J., and Ma, S.: Chemical and isotopic composition of humic-like substances (HULIS) in ambient aerosols in Guangzhou, South China, Aerosol Sci. Tech., 46, 533-546, 2012.

Subbalakshmi, Y., Patti, A. F., Lee, G. S. H., and Hooper, M. A.: Structural characterization of macromolecular organic material in air particulate matter using py-GC-MS and solid state C-13NMR, J. Environ. Monitor., 2, 561-565, 2000.

Suzuki, Y., Kawakami, M., and Akasaka, K.: H-1 NMR application for characterizing water-soluble organic compounds in urban atmospheric particles, Environ. Sci. Technol., 35, 2656-2664, 2001.

Tagliavini, E., Moretti, F., Decesari, S., Facchini, M. C., Fuzzi, S., and Maenhaut, W.: Functional group analysis by $\mathrm{H}$ $\mathrm{NMR} / \mathrm{chemical}$ derivatization for the characterization of organic aerosol from the SMOCC field campaign, Atmos. Chem. Phys., 6, 1003-1019, doi:10.5194/acp-6-1003-2006, 2006.

Takahashi, Y., Sasaki, K., Nakamura, S., Miki-Hirosige, H., and Nitta, H.: Aerodynamic size distribution of particles emitted from the flowers of allergologically important plants, Grana, 34, 45-49, 1995.

Timonen, H., Saarikoski, S., Aurela, M., Saarnio, K., and Hillamo, R.: Water soluble organic carbon in urban aerosols: 
concentrations, size distributions and contributions to particulate matter, Boreal Environ. Res., 13, 335-346, 2008.

VandenBoer, T. C., Petroff, A., Markovic, M. Z., and Murphy, J. G.: Size distribution of alkyl amines in continental particulate matter and their online detection in the gas and particle phase, Atmos. Chem. Phys., 11, 4319-4332, doi:10.5194/acp-11-43192011, 2011.

Van Vaeck, L. and Van Cauwenberghe, K. A.: Characteristic parameters of particle size distributions of primary organic constituents of ambient aerosols, Environ. Sci. Technol., 19, 707-716, 1985.

Widory, D., Roy, S., Le Moullec, Y., Goupil, G., Cocherie, A., and Geuerrot, C.: The origins of atmospheric particles in Paris: a view through carbon and lead isotopes, Atmos. Environ., 38, 953-961, 2004.

Wishart, D. S., Knox, C., Guo, A. C., Eisner, R., Young, N., Gautam, B., Hau, D. D., Psychogios, N., Dong, E., Bouatra, S., Mandal, R., Sinelnikov, I., Xia, J., Jia, L., Cruz, J. A., Lim. E., Sobsey, C. A., Shrivastava, S., Huang, P., Liu, P., Fang, L., Peng, J., Fradette, R., Cheng, D., Tzur, D., Clements, M., Lewis, A., De Souza, A., Zuniga, A., Dawe, M., Xiong, Y., Clive, D., Greiner, R., Nazyrova, A., Shaykhutdinov, R., Li, L., Vogel, H. J., and Forsythe, I.: HMDB: a knowledgebase for the human metabolome, Nucleic Acids Res., 37, D603-10, doi:10.1093/nar/gkn810, 2009.
Wozniak, A. S., Shelley, R. U., Sleighter, R. L., Abdulla, H. A. N., Morton, P. L., Landing, W. M., and Hatcher, P. G.: Relationships among aerosol water soluble organic matter, iron and aluminum in European, North African, and marine air masses from the 2010 US GEOTRACES cruise, Mar. Chem., 154, 24-33, 2013.

Yamamoto, N., Bibby, K., Qian, J., Hospodsky, D., Rismani-Yazdi, H., Nazaroff, W. W., and Peccia, J.: Particle-size distribution and seasonal diversity of allergenic and pathogenic fungi in outdoor air, ISME J., 6, 1801-1811, doi:10.1038/ismej.2012.30, 2012.

Zhang, Y., Obritz, D., Zielinska, B., and Gertler, A.: Particulate emissions from different types of biomass burning, Atmos. Environ., 72, 27-35, 2013. 